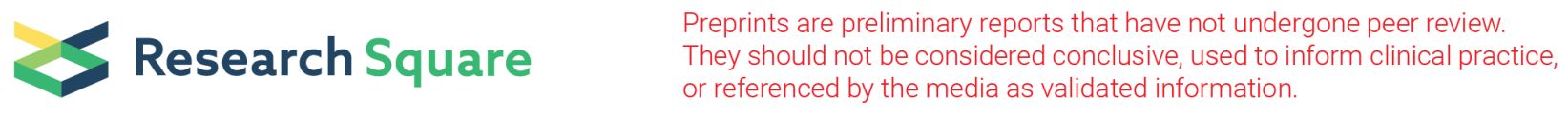

\title{
Structural Characterization, DFT Geometry Optimization, Cyclic Voltammetry and Biological Assay of (Tellurite-pyridine) Mixed Ligandcomplexesof Cd(II)
}

\author{
M. N. Abd El-Hady \\ Mansoura University \\ E. A. Gomaa \\ Mansoura University \\ Rania Zaky ( $\square$ rania.zaky@yahoo.com) \\ Mansoura University \\ S. E. Elafifi \\ Mansoura University
}

\section{Research Article}

Keywords: Structural characterization, DFT computational simulation, cyclic voltammetry, biological activities

Posted Date: January 3rd, 2022

DOl: https://doi.org/10.21203/rs.3.rs-1203068/v1

License: () (1) This work is licensed under a Creative Commons Attribution 4.0 International License. Read Full License 


\section{Abstract}

This research work presents spectral characterizations (IR, ${ }^{1} \mathrm{H}$ NMR and ${ }^{13} \mathrm{C}$ NMR) of anionic tellurito Cd(II) complexes that prepared using cyanopyridine derivatives as a polydentate ligands. Also, X-ray based techniques involving (EDX and XRD) are applied for cadmium complexes to realize elemental composition and average crystallographic coherence. Moreover, the electrochemical studies represented on cyclic voltammetry are determined for Cd) II) in (absence/presence) of ligands to detect the role of complexation in solution measurements. All the previous experimental investigations are supported with molecular modeling of the geometric optimized structures based on density function theory (DFT) for all compounds accompanied by the calculations of different energetic parameters such as $\mathrm{E}_{\text {HOMO }}$ and $\mathrm{E}_{\mathrm{LUMO}}$. Finally, anti-microbial (antibacterial and antifungal), anti-oxidant and Bleomycin dependent DNA damage are screened for all samples to predict the influence of metal complex formation on the biological activity of pyridyl ligands besides their priority.

\section{Introduction}

Transitional metals can exhibit a wide range of coordination and reactivity features that can be employed with pyridyl ligands to prepare complexes. Transition metal complexes display unique and impressive characteristics such as changing oxidation states and the ability to produce particular reactions with different biomolecules [1, 2]. Therefore, the coordination between transition metals with pyridyl ligand swould prevent the resistance by microbes and enhance the antimicrobial activity of the pyridine derivative through new mechanisms of inhibition [3]. It was noticed that some metal-drug complexes are more effective than their pure drug $[4,5]$.

Various studies have been reported concerning the biological activities of pyridyl ligands metal complexes, involving their anticancer [6-8], antibacterial [911], antifungal [12], anticonvulsant [13] and antiviral properties [14-18]. On the parallel side, inorganic anions like selenite ion, $\mathrm{SeO}_{3}{ }^{2-}$ and sulfite ion, $\mathrm{SO}_{3}{ }^{2-}$ were used as ligands in transition metal complexes. Herein, we are reporting to the preparation and characterization mixed ligand $\left.\left(\mathrm{TeO}_{3}{ }^{2-}-\mathrm{pyridine}\right) \mathrm{Cd}^{-} \mathrm{II}\right)$ complexes accompanied by theoretical, electrochemical and biological applications.

\section{Experimental}

The used potassium chloride, cadmium chloride, absolute ethanol, DMF and diethyl ether were provided from Sigma Aldrich Co. Sodium sulphate was provided from (ADWIC), 2-amino pyridine and phenyl isothiocyanate were from Alfa Aesar Co. Sodium tellurite $\left(\mathrm{Na}_{2} \mathrm{TeO}_{3}\right)$ was from BDH Chemicals Ltd Poole England. All of the chemicals were used without any purification processes.

\subsection{Preparation of ligands}

\subsubsection{Preparation of 2-cyano-N-(pyridin-2-yl)acetamide (HCPA)}

2-cyano-N-(pyridin-2-yl) acetamide (HCPA) (Scheme 1) was prepared by addition of 3-(3, 5-dimethylpyrazol-1-yl)-3-oxopropionitrile (0.01 mol) to a solution of 1.0 equiv. of 2-aminopyridine in toluene $(10-15 \mathrm{ml})$, then the mixture was refluxed for $15 \mathrm{~min}$ and stirred at room temperature. The formed 2-cyano- $\mathrm{N}$-(pyridin-2yl) acetamide was filtered, washed with diethyl ether and dried (m.p $\left.155^{\circ} \mathrm{C}\right)$ [19-23].

\subsubsection{Preparationof2-cyano-3-mercapto-3-(phenylamino)-N-(pyridin-2-yl)acrylamide(HCMPPA)}

A mixture of 2-cyano- $\mathrm{N}$-(pyridin-2-yl) acetamide $(0.01 \mathrm{~mol})$ and solid $\mathrm{KOH}(0.01 \mathrm{~mol})$ in $\mathrm{DMF}(20 \mathrm{~mL})$ were stirred for 5 min at room temperature then phenyl isothiocyanate $(0.01 \mathrm{~mol})$ was added dropwisely. The mixture was stirred for $12 \mathrm{~h}$ and then poured over crushed ice containing $\mathrm{HCl}$. The ppt formed was filtered off, washed with water, dried and finally, recrystallized from EtOH/DMF to get 2-cyano-3-mercapto-3-(phenyl amino)-N-(pyridin-2-yl) acrylamide (m.p $187^{\circ} \mathrm{C}$ ) as explained in Scheme 2 [24-26].

\subsection{Preparation of mixed ligand complexes}

To a hot solution of ligands (HCPAand HCMPPA) in ethanol and sodium tellurite $\left(\mathrm{Na}_{2} \mathrm{TeO}_{3}\right)$ in distilled deionized water, a solution of cadmium chloride in distilled water was added slowly as shown in Scheme 3, 4. The mixture was heated in reflux for (3-4) hr. The isolated solid complexes were filtered off, washed many times with hot distilled $\mathrm{H}_{2} \mathrm{O}$ and/or $\mathrm{EtOH}$ and finally dried in a vacuum desiccator over anhydrous $\mathrm{CaCl}_{2}$.

\subsection{Analysis of complexes}

Carbon, hydrogen and nitrogen percentage for ligands and their complexes were performed in Microanalytical Unit, Azhar University, Egypt. Complexometric analysis was utilized to predict the contents of $\mathrm{Cd}(\mathrm{II})$ in the prepared complexes. While, the gravimetric analysis was employed to calculate the content of $\mathrm{Cl}^{-}$ which was determined as $\mathrm{AgCl}$.

\subsection{Instrumentation}

All the spectroscopic techniques (IR, ${ }^{1} \mathrm{HNMR},{ }^{13} \mathrm{CNMR}$, EDX and XRD) utilized to illustrate the structure of the solid compounds are collected and clarified in Scheme (1S).

\subsection{Cyclic Voltammetry}

The electrochemical cell consists of three electrodes: (i) a reference electrode represented on $\mathrm{Ag} / \mathrm{AgCl} / \mathrm{KCl}_{\text {saturated, }}$ (ii) GCWE (glassy carbon working electrode) as a working electrode and (iii) an auxiliary electrode which is a platinum wire. These electrodes immersed in $30 \mathrm{ml}$ from $0 . \mathrm{I} \mathrm{M} \mathrm{KCl} \mathrm{supporting}$ 
electrolyte and connect with potentiostat of the type DY 2100 where the US convention is used to report CV data.

\subsection{Molecular modeling}

Density functional theory (DFT) modeling of the molecular structure and frontier molecular orbitals (HOMO/LUMO) is accomplished by using the Beck'sthree parameter exchange functional along with the Lee-Yang-Parr non local correlation functional (B3LYP) [27]. We used two different basis sets. We used 6-311+g $(d, p)$ basis set for ligands and the Los Alamos National Laboratory basis set of double-zeta quality (LANL2DZ) for Cd complexes [28] in Gaussian 09 package in order to find the structural and electronic parameters [29].

\subsection{Biological activities}

\subsubsection{Antifungal and antibacterial activities}

MIC (the minimum inhibitory concentration of the substance) was determined using the disc diffusion method as explained in Scheme (2S).

\subsubsection{Antioxidant activity}

The advantage of ABTS method is that possessing an extra free radical more than other techniques. Where, a stable color was produced over (1hr) in this reaction. The procedures of this method are explained in Scheme (3S).

\subsubsection{Colorimetric assay of BMC-dependent DNA damage}

The colorimetric assay for the prepared compounds and the ligands against DNA damage was illustrated in Scheme (4S) [30].

\subsection{Molecular docking}

Molecular docking calculations were carried out using docking server [31]. Gasteiger partial charges were added to the atoms of ligand. Non-polar hydrogen atoms were conjoined and rotatable bonds were identified. With the help of AutoDock tools [32], essential hydrogen atoms, Kollman united atom type charges and solvation parameters were added. Affinity grid points and spacing of $0.375 \AA$ Aere created using the Autogrid program [33]. Auto Dock parameter set- and distance-dependent dielectric functions were used to calculate the van der Waals and the electrostatic terms, respectively. Docking simulations were done by the use of the Lamarckian genetic algorithm (LGA) and the Solis \& Wets local search method [34]. Orientation, initial position and torsions of the molecules of ligand were set randomly. All rotatable torsions were liberated during docking. Every docking experiment was derived from 10 different runs that were set to end after a maximum of 250000 energy evaluations. The population size was set to 150 . During the search, a translational step of $0.2 \AA$ and quaternion and torsion steps of 5 were applied.

\section{Results And Discussion}

\subsection{Chemical composition and Physical properties}

The practical elemental analysis results of the investigated compounds refer to great resemblances with the calculated chemical compositions as shown in Tables (1 \& 2) in addition to some of characteristic physical properties.

\subsection{FT-IR}

\subsubsection{IR spectra of 2-cyano-N-(pyridin-2-yl)acetamide (HCPA) and its Cd(II) complex}

The most characteristic infrared bands of HCPAand its Cd (II) complex werelisted in Table 3 and represented graphically in (Figure 1S). There were six distinct absorption bands in the IR spectrum of HCPA at (3038 medium, 2257 medium-sharp, 1672 strong-sharp, 3345 medium-sharp, 1635 strong and 776 mediumsharp) $\mathrm{cm}^{-1}$ which represented stretching frequencies of methylene $v_{a s}\left(\mathrm{CH}_{2}\right)$ [35], cyano $v(\mathrm{C} \equiv \mathrm{N})$ [36], amide carbonyl $v(\mathrm{NH}-\mathrm{C}=0)$ [37], secondary amine $v(\mathrm{NH})$ [38], aromatic azomethine $v(\mathrm{C}=\mathrm{N})_{\text {pyridine }}[39]$ and pyridine ring breathing vibrational mode, respectively.

While IR spectrum of $\mathrm{Na}_{2}\left[\mathrm{Cd}(\mathrm{CPA})\left(\mathrm{TeO}_{3}\right)\left(\mathrm{H}_{2} \mathrm{O}\right) \mathrm{Cl}\right] .2 \mathrm{H}_{2} \mathrm{O}$ complex revealed that $\mathrm{HCPA}$ ligand behaved as mononegative bidentate chelating agent via enolized

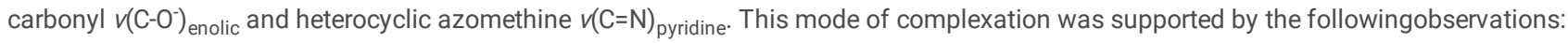

1. Shift in band position of $v(\mathrm{C}=\mathrm{N})_{\text {pyridine }}$ to lower wave number $1624 \mathrm{~cm}^{-1}$ while $v(\mathrm{NH})$ and $v(\mathrm{C} \equiv \mathrm{N})$ remained nearly at the same positions without change.

2. Disappearance of $v(\mathrm{~N}-\mathrm{C}=0)$ and $v\left(\mathrm{CH}_{2}\right)$ as a result of enolization process with simultaneous appearance of new $v(\mathrm{C}=\mathrm{C})_{\text {aliphatic }}$ at $1633 \mathrm{~cm}{ }^{-1}$ and $v(\mathrm{C}$ $\left.0^{-}\right)_{\text {enolic }}$ at $1265 \mathrm{~cm}^{-1}[40]$.

3. Appearance of new bands at 525,422 and $677 \mathrm{~cm}^{-1}$ which referred to $v(\mathrm{Cd}-\mathrm{O}), v(\mathrm{Cd}-\mathrm{N})$ [41] and $v(\mathrm{Te}-0)$ [42], respectively.

\subsubsection{IR spectra of 2-cyano-3-mercapto-3-(phenyl amino)-N-(pyridin-2-yl)acrylamide(HCMPPA) and its Cd(II) complex}

The most characteristic infrared bands of HCMPPA and its Cd (II)complexwerelisted in Table 4 and represented graphically in (Figure 2S). The IR spectrum of HCMPPA displayed eight essential bands at $3221,3103,2929,2193,1644,1549,1598$ and $840 \mathrm{~cm}^{-1}$ which were referral to $v(\mathrm{NH})_{\mathrm{Phenyl}}, v(\mathrm{NH})_{\mathrm{Pyridyl}}[38]$, thiol $v(\mathrm{SH})$ [43], cyano $v(\mathrm{C} \equiv \mathrm{N})$ [36], amide carbonyl $v(\mathrm{NH}-\mathrm{C}=0)$ [37], aliphatic $v(\mathrm{C}=\mathrm{C})$ [44], $v(\mathrm{C}=\mathrm{N})_{\text {Pyridine }}$ and pyridine ring breathing vibrational mode [39], respectively. 
While IR spectrum of $\mathrm{Na}_{2}\left[\mathrm{Cd}(\mathrm{CMPPA})\left(\mathrm{TeO}_{3}\right)\left(\mathrm{H}_{2} \mathrm{O}\right) \mathrm{Cl}\right] \cdot 2 \mathrm{H}_{2} \mathrm{O}$ complex revealed that HCMPPA acted as mononegative bidentate ligand according to the following variations:

1. Disappearance of $v(\mathrm{NH})_{\text {Pyridyl }}$ and $v(\mathrm{C}=0)$ as a result of enolization process with simultaneous appearance of new $v(\mathrm{C}=\mathrm{N})$ at $1626 \mathrm{~cm}^{-1}$ and $v\left(\mathrm{C}-\mathrm{O}^{-}\right)_{\text {enolic }}$ at $1150 \mathrm{~cm}^{-1}[43]$.

2. Shift in band position of $v(\mathrm{C}=\mathrm{N})$ pyridine to lower wave number $1601 \mathrm{~cm}^{-1}$ While the other groups remained nearly at the same positions.

3. Appearance of new bands at 520,470 and $681 \mathrm{~cm}^{-1}$ which referred to $v(\mathrm{Cd}-0), v(\mathrm{Cd}-\mathrm{N})[41]$ and $v(T e-0)[42]$, respectively.

\section{3. ${ }^{1} \mathrm{H}$ NMR and ${ }^{13} \mathrm{C}$ NMR spectra}

\subsection{1. ${ }^{1} \mathrm{H}$ NMR and ${ }^{13} \mathrm{CNMR}$ spectra of 2-cyano-N-(pyridin-2-yl)acetamide (HCPA) and its Cd(II) complex}

The ${ }^{1} \mathrm{H}$ NMR spectrum of HCPA in DMSO (Figure 1) detected two singlet signals at 10.81 and 3.58 ppm characteristic for secondary imide proton (-NH) and methylene protons $\left(-\mathrm{CH}_{2}\right)$, respectively. Also, signals at $6.55-8.31 \mathrm{ppm}$ were assigned to aromatic protons of pyridine ring.

The ${ }^{13} \mathrm{C}$ NMR spectrum of HCPA in DMSO (Figure $2 \mathrm{~A}$ ) showed sharp peaks at 25.74, 116.82 and 166,87 ppm characteristic for methylene carbon (- $\mathrm{CH}_{2}$ ), cyano carbon $(C \equiv N)$ and carbonyl carbon $(C=0)$, respectively. The signals at $118.23,138.96,148.61,113.96$ and 153.44 ppm were assigned to carbons of pyridine ring.

While, the ${ }^{13} \mathrm{C}$ NMR spectrum of $\mathrm{Na}_{2}\left[\mathrm{Cd}(\mathrm{CPA})\left(\mathrm{TeO}_{3}\right)\left(\mathrm{H}_{2} \mathrm{O}\right) \mathrm{Cl}\right] .2 \mathrm{H}_{2} \mathrm{O}$ complex in DMSO (Figure 2B) detected singlet signals at 116.24 ppm characteristic for cyano carbon $(\mathrm{C} \equiv \mathrm{N})$. It also showed signal at $160.20 \mathrm{ppm}$ that belonged to enolic carbon $\left(\mathrm{C}^{-} \mathrm{O}^{-}\right)$rather than carbonyl group in ligand and signal at 88.97 ppm referral to ethylene carbon $(-\mathrm{CH}=\mathrm{C})$. The signals at $150.12,112.25,148.15,127.36$ and 137.43 ppm indicated carbons of pyridine ring.

\subsection{2. ${ }^{1} \mathrm{H} N M R$ and ${ }^{13} \mathrm{CNMR}$ spectra of 2-cyano-3-mercapto-3-(phenyl amino)-N-(pyridin-2-yl)acrylamide (HCMPPA) and its Cd(II) complex}

The ${ }^{1} \mathrm{H}$ NMR spectrum of HCMPPA in DMSO (Figure 3 ) detected singlet signals at 13.865 ppm characteristic for thiol proton (-SH). It also showed two singlet

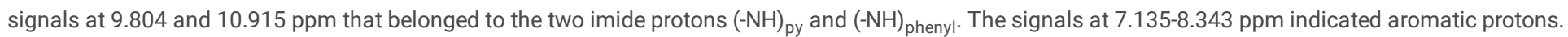

The ${ }^{13} \mathrm{C}$ NMR spectrum of HCMPPA in DMSO (Figure $4 \mathrm{~A}$ ) detected two signals at 116.38 and 168.35 ppm characteristic for cyano carbon (C $\equiv \mathrm{N}$ ) and carbonyl carbon $(\mathrm{C}=0)$, respectively.In addition, two signals appeared at 88.97 and $180.06 \mathrm{ppm}$ assigned to $(\mathrm{C}=\mathrm{C})$ and $(=\mathrm{C}$-SH), respectively. The signals at $118.40-$ $140.88 \mathrm{ppm}$ indicated aromatic carbons.

While, the ${ }^{13} \mathrm{C}$ NMR spectrum of $\mathrm{Na}_{2}\left[\mathrm{Cd}(\mathrm{CMPPA})\left(\mathrm{TeO}_{3}\right)\left(\mathrm{H}_{2} \mathrm{O}\right) \mathrm{Cl}\right] .2 \mathrm{H}_{2} \mathrm{O}$ complexin DMSO (Figure $4 \mathrm{~B}$ ) detected two signalsat 116.24 and 162.49 ppm characteristic for cyano carbon $(\mathrm{C} \equiv \mathrm{N})$ and enolic carbon $(=\mathrm{C}-0)$, respectively.In addition, two signals appeared at 77.13 and $166.87 \mathrm{ppm}$ assigned to $(\mathrm{C}=\mathrm{C})$ and $(=\mathrm{C}-\mathrm{SH})$, respectively. The signals at $120.49-151.78 \mathrm{ppm}$ indicated aromatic carbons.

\subsection{EDX and XRD examinations}

EDX analysis data showed peaks corresponding to the elements $(\mathrm{C}, \mathrm{N}, \mathrm{O}, \mathrm{S}, \mathrm{Cl}, \mathrm{Cd}, \mathrm{Na}$ and $\mathrm{Te})$ making up the composition of the samples being analyzedas shown in (Figures $5 \& 6$ ).

X-ray diffraction was carried out at room temperature using $\left(\mathrm{Cu}, \mathrm{K}_{\mathrm{a}}\right)$ radiation. The diffraction pattern (Figure 7$)$ was measured in the range of $10^{\circ}<2 \theta<80^{\circ}$ [45] and displayed sharp peaks indicating that the formation of a well-defined crystalline structure. The crystallite size is measured by Deby-Scherrer equation (4) through applying FWHM of the characteristic peaks:

$\underline{\beta}=0.94 \lambda /(S \cos \theta)$

Where, "Cu/Ka $(\lambda)=1.5406 \mathrm{~A}^{\circ},(\theta)$ is the diffraction angle, $(\mathrm{S})$ is the crystallite size and $(\underline{\beta})$ is the line thickness at half highest height". Bragg equation (5) can be used to measure the inner crystal plane $\mathrm{d}$-spacing value as follow:

$\mathrm{n} \lambda=2 \mathrm{~d} \sin (\theta) \quad$ at $\mathrm{n}=1 \quad(2)$

The magnitudes of Lattice parameters and the particle size were listed in Table 5.

\subsection{Molecular chemical parameters}

DFT (Density function theory) is adjusted to calculate quantum energies, the most important of which are $\mathrm{E}_{\mathrm{HOMO}}$ (Energy of the highest occupied molecular orbital) and $\mathrm{E}_{\mathrm{LUMO}}$ (Energy of the lowest unoccupied molecular orbital), because $\mathrm{E}_{\text {gap }}$ (the difference between them) shows the stability of the compounds under study. The molecular structures with atom numbering of ligandsand their complexes are shown in (Figures 8 \& 9). After the computational modeling simulation process, the following significant remarks can be recorded:

- $\mathrm{E}_{\mathrm{HOMO}}$ and $\mathrm{E}_{\mathrm{LUMO}}$ as shown in (Figures 10 \& 11) are (-ve) values indicating the constancy of ligands and their complexes.

- Bond lengths as shown in (Figures 3S \& 4S) and Tables (1S-4S) are correlated with the frequencies of the experimental Infra-Red bond expansion. 
- Bond angles of the compounds shown in (Figures. $5 \mathrm{~S} \& 6 \mathrm{~S}$ ) and Tables (5S-8S) reveal that $\mathrm{Na}_{2}\left[\mathrm{Cd}(\mathrm{CPA})\left(\mathrm{TeO}_{3}\right)\left(\mathrm{H}_{2} \mathrm{O}\right) \mathrm{Cl}\right] .2 \mathrm{H}_{2} \mathrm{O}$ as well as Na${ }_{2}[\mathrm{Cd}(\mathrm{CMPPA})$ $\left.\left(\mathrm{TeO}_{3}\right)\left(\mathrm{H}_{2} \mathrm{O}\right) \mathrm{Cl}\right] .2 \mathrm{H}_{2} \mathrm{O}$ complexes had octahedral geometry.

- The energies of (FMO) frontier molecular orbitals ( $\left.\mathrm{E}_{\mathrm{HOMO}} / \mathrm{E}_{\mathrm{LUMO}}\right)$ can beemployed $\mathrm{d}$ to derive number of quantum parameters like energy ( $\mathrm{E}_{\mathrm{gap}}$ : band gap), ( $\omega$ : global electrophilicity index), ( $\eta$-: hardness), ( $\mu$ : chemical potential), ( $\chi$ :electronegativity) and ( $\sigma$ : Softness) [46]as shown in (Tables 6 \& 7).

$E_{\mathrm{gab}}=\mathrm{E}_{\mathrm{HOMO}}-\mathrm{E}_{\mathrm{LUMO}}$
$\eta^{-}=1 / 2\left(\mathrm{E}_{\mathrm{LUMO}}-\mathrm{E}_{\mathrm{HOMO}}\right)$
$\mu=\omega^{2} / 2$
$\mu=-\chi=1 / 2\left(\mathrm{E}_{\mathrm{LUMO}}+\mathrm{E}_{\mathrm{HOMO}}\right)$
$\chi \chi=-1 / 2\left(\mathrm{E}_{\mathrm{LUMO}}+\mathrm{E}_{\mathrm{HOMO}}\right)$
$\sigma=1 / \eta^{-}$

\subsection{Molecular Electrostatic Potentialmapping}

MEP of all compoundsas presented in (Figures 12 \& 13) are characterized by three colored zones [47] as follow: (i) the first zone hasa red color which denotes to the high electron density region which responsible for the electrophilic attack reactions, (ii) the second green zone elucidates to the neutral electrostatic potential region and (iii) the blue colored are as with low electron density correspondingto the nucleophilic attack region.

\subsection{Cyclic Voltammetry studies of $\mathrm{CdCl}_{2}$}

\subsubsection{Electrochemical behavior of $\mathrm{Cd}(\mathrm{II})$ in absence of HCPA with the suggested mechanism at $301.15 \mathrm{~K}$}

The redox behavior of $\mathrm{CdCl}_{2}$ in $0.1 \mathrm{M} \mathrm{KCl}$ as supporting electrolyte was examined by using cyclic voltammetry technique. Glassy carbon electrode (GCE) was used as working electrode within potential window ( $1 \mathrm{~V}$ to $-1.2 \mathrm{~V}$ ) and scan rate $0.1 \mathrm{~V} / \mathrm{s}$ at $301.15 \mathrm{~K}$. Cd (II) solution was electroactive as it gave one cathodic peak and one anodic peak in cyclic voltammogram as shown in (Figure 14).

In the forward scan, $\left(\mathrm{Cd}^{2+} / \mathrm{Cd}\right)$ cathodic potential was at $-0.9235 \mathrm{~V}$ while in the reverse scan, the $\left(\mathrm{Cd} / \mathrm{Cd}^{2+}\right)$ anodic potential was at $-0.6507 \mathrm{~V}$. Thus, the $\mathrm{Cd}{ }^{2+}$ system was reversible and involved the transfer of two electrons. The redox mechanism can be represented by (Eqns. 9 and 10)

\section{Reduction: \\ $\mathrm{Cd}^{2+}+2 \mathrm{e}^{-} \longrightarrow \mathrm{Cd}$ \\ Oxidation:

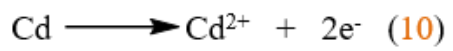

\subsubsection{Cyclic Voltammetry theoretical approach}

Applying the Randles-Sevcik equation (11), the analyte diffusion coefficient (D) in $\mathrm{cm}^{2} . \mathrm{s}^{-1}$ was given as follow [48, 49]:

$I_{p}=\left(2.69 \times 10^{5}\right) n^{3 / 2} A C v^{1 / 2} D^{1 / 2}$

Where" $\left(I_{p}\right)$ is the current in Ampere, $(n)$ is the number of electrons involved in the reaction $(A)$ is surface area of the working electrode in $\mathrm{cm}^{2},(C)$ is metal cation concentration in mol.cm ${ }^{-3}$ and $(v)$ is scan rate in volts. $\mathrm{sec}^{-1}$ ". Also, $\left(\Delta \mathrm{E}_{\mathrm{Peak}}\right)$ the difference potential and (a) the charge transfer coefficient of electrons are calculated using equations (12) and (13) [50,51].

$\Delta \mathrm{E}_{\mathrm{p}}=\mathrm{E}_{\mathrm{p}, \mathrm{a}}-\mathrm{E}_{\mathrm{p}, \mathrm{c}}(12)$

an $=1.857 R T /\left(E_{p c}-E_{p c / 2}\right)$

where, " $E_{p c / 2}$ is the half-wave potential of the cathodic peak, $\left(R=8.314 \mathrm{~J} \cdot \mathrm{mol}^{-1} \cdot \mathrm{K}^{-1}\right)$ is the universal gas constant, $(T)$ is the temperature in kelvin. The heterogeneous charge transfer rate constant $\left(k_{s}\right)$ in $\mathrm{cm} / \mathrm{sec}$ can be calculated by the following equation (14) [52].

$\mathrm{k}_{\mathrm{s}}=2.18[\mathrm{D} \text { an } \mathrm{F} \mathrm{v} / \mathrm{RT}]^{1 / 2} \exp \left[\mathrm{a}^{2} \mathrm{nF} \Delta \mathrm{E}_{\mathrm{P}} / \mathrm{RT}\right]$

Where, " $(\mathrm{F}=96485.33$ coulombs $)$ is Faraday constant". The cyclic voltammetric parameters for an anodic and cathodic peak are calculated and listed in Table (8). The surface coverage ( $\Gamma$ : the number of adsorbed species on a surface divided by the number of species in a filled monolayer on that surface) in mol.cm ${ }^{-2}$ as well as $(\mathrm{Q})$ the quantity of charge that consumed during the reduction reaction or the quantity of charge that produced as a result of the oxidation can be evaluated from equations (15) and (16), respectively $[53,54]$. As $\mathrm{CdCl}_{2}$ concentration increases, most of the cyclic voltammetric parameters $\left(\mathrm{I}_{p}, \Delta \mathrm{E}_{\mathrm{p}}, \Gamma\right.$ and $\left.\mathrm{Q}\right)$ increase leading to more diffusion processes takes place between the bulk of solution and GCWE surface.

$\Gamma=$ ip $4 R T / n^{2} F^{2} A v$

$\mathrm{Q}=\mathrm{n} F \mathrm{~F} \Gamma$ 


\subsubsection{Cyclic voltammetry response of Cd(II) in presence of HCPA}

On adding $\mathrm{HCPA}$ to $\mathrm{CdCl}_{2}$ solutionin $0.1 \mathrm{M} \mathrm{KCl}$ solution at GCE within potential range from $1 \mathrm{~V}$ to $-1.2 \mathrm{~V}$ and scan rate $0.1 \mathrm{~V} / \mathrm{s}$ as shown in (Figure 15 ), it was observed that there was shift in potential for both reduction and oxidation peaks. Cathodic current and anodic current also decreased with increasing concentration of HCPA The voltammogram demonstrates the effect of complexation between HCPA and Cd(II) ions. The diffusion of species (D), the redox reaction rates (an) and the cyclic voltammetry parameters ( $\Gamma$ and Q) decrease as aresult of complex formationin solution and weakness of GCWE role ( less an), the change in the resultsshown in Table (9).

\subsubsection{The stability constant and Gibbs free energies for the $\left(\mathrm{Cd}^{2+} / \mathrm{HCPA}\right)$ complex}

The stability constants $\left(\beta_{\mathrm{ML}}\right)$ and Gibbs free energies $(\Delta \mathrm{G})$ increase by further addition of $H C P A$ to the $\mathrm{Cd}(\mathrm{II})$ ions indicating the sequential and progressive construction to form a stable complexin thesolution system as illustrated in Table (10). The following equations (17), (18) and (19) are used to calculate $\beta_{\mathrm{ML}}$ and $\Delta \mathrm{G}$ :

$E^{\circ}=\left(E_{p a}+E_{p c}\right) / 2 \quad(17)$

$\Delta \mathrm{E}^{\circ}=\mathrm{E}_{\mathrm{C}}^{\circ}-\mathrm{E}_{\mathrm{M}}^{\circ}=2.303(\mathrm{RT} / \mathrm{nF}) \underline{\mathrm{x}}\left(\log \beta_{\mathrm{ML}}+\mathrm{j} \log \mathrm{C}_{\mathrm{L}}\right)(18)$

$\Delta G=-2.303 R T \log \beta_{M X} \quad(19)$

Where, $\left(E_{M}^{\circ}\right)$ is the formal peak potential of metal ion at zero ligand addition, $\left(E_{M I}^{\circ}\right)$ is the formal peak potential of complex at each ligand addition, $(j=$ $[\mathrm{L}] /[\mathrm{M}])$ is the molar ratio and $\left(\mathrm{C}_{\mathrm{L}}\right)$ is molar ligand concentration. We can observe that as the ligand concentration increased as $\left(\beta_{\mathrm{ML}}\right.$ and $\left.\Delta \mathrm{G}\right)$ increased.

\section{.8. Biological activities}

\subsubsection{Antimicrobial studies}

The activity index percent (\%Activity Index) of ligands (HCPA and HCMPPA) and their chelates against "Staphylococcus aureus" as agram-positive bacteria, "Escherichia coli" asgram-negative bacteria and "Candida albicans" as a pathogenic fungus was calculated by equation $(20)[55,56]$ and listed in the Tables (9S \& 10S).

$\%$ Activity Index $=\frac{\text { inhibition zone of test compound (diametre) }}{\text { inhibition zone of standard (diametre) }} \mathrm{X} 100$

In light of the resultsof biological study charts as shown in (Figures 16 \& 17), we can notice the following:

- According to the activity index data, it has been found that HCPA and its Cd (II) complex showed low antibacterial activity toward E. coli and moderate values toward S.aureus. For antifungal activity, $\mathrm{HCPA}$ and $\mathrm{Na}_{2}\left[\mathrm{Cd}(\mathrm{CPA})\left(\mathrm{TeO}_{3}\right)\left(\mathrm{H}_{2} \mathrm{O}\right) \mathrm{Cl}_{2} .2 \mathrm{H}_{2} \mathrm{O}\right.$ complex exhibited moderate values against $C$. albicans.

- While, HCMPPA and its Cd (II) complex had high antimicrobial activity. A glance of data indicated that:

- HCMPPA revealed the most potent antimicrobial activity against all organisms .

- HCMPPA and its Cd (II) complex were more effective against $S$. aureus than E. coli.

\subsubsection{Antioxidant studies}

$\operatorname{ABTS}(2,2$ '-azinobis [3-ethylbenzthiazoline]-6-sulfonic acid) method was applied to the compounds to evaluatetheir antioxidant ranking [57]. The standard antioxidant (+ ve control) is L-ascorbic acid [58]. All compounds as in (Figures 18 \& 19) and Tables (11S \& 12S )show that:

- HCPA and its complexes exhibited moderate antioxidant activity, $\mathrm{HCPA}(30 \%)$ and $\mathrm{Na}_{2}\left[\mathrm{Cd}(\mathrm{CPA})\left(\mathrm{TeO}_{3}\right)\left(\mathrm{H}_{2} \mathrm{O}\right) \mathrm{Cl}\right] .2 \mathrm{H}_{2} \mathrm{O}$ complex $(31.6 \%)$.

- HCMPPA and its complexes had high antioxidant activity in comparison with standard ascorbic acid. HCMPPA showed the highest antioxidant activity $(67.2 \%)$ then $\mathrm{Na}_{2}\left[\mathrm{Cd}(\mathrm{CMPPA})\left(\mathrm{TeO}_{3}\right)\left(\mathrm{H}_{2} \mathrm{O}\right) \mathrm{Cl}\right] .2 \mathrm{H}_{2} \mathrm{O}$ complex $(50.4 \%)$.

\subsubsection{BMC-dependent DNA damage}

The bleomycin (BMC) is a member from glycopeptides antibiotics which is utilizes as antitumor agents. The bleomycin assay was certified as a specific method to estimate the pro-oxidant activity of drugs and food antioxidants. BMC binds iron ions and DNA. If the compounds are able to reduce the bleomycin$\mathrm{Fe}(\mathrm{III})$ into bleomycin-Fe(II), DNA degradation in this system would be stimulated, resulting in a (+ve) pro-oxidant activitytest [59]. The protective activity against DNA damage induced by the (BMC - iron) complex was screened for ligands (HCPA and HCMPPA) and their chelates. The results obtained were included in Tables (13S \& 14S) and offered in (Figures 20 \& 21) with a schematic representation in Figure (7S) where it was observed that HCPA and its complexes had low protective activity against DNA damage induced by the bleomycin iron complex compared to the results of ascorbic acid as a standard compound. While, HCMPPA and its complexes had high protection against DNA damage induced by the bleomycin iron complex.

\subsection{Molecular docking}

Molecular docking is an effective tool in computer drug design. Molecular docking of 2-cyano-N-(pyridin-2-yl) acetamide (HCPA) and 2-cyano-3-mercapto-3(phenyl amino)-N-(pyridin-2-yl )acrylamide (HCMPPA) was carried out with receptors of Escherichia coli (PDB code: 1xk6), Staphylococcus aureus (PDB code: 
6gyw), Candida albicans (PDB code: 3ppc) and Covid 19 (PDB code: 7jpy).The docking studies showed an interaction between ligands and receptors as cleared in (Figures 22-25). The calculated bending energies of ligands as well as some parameters with the selected receptors were collected in Tables11-14. The 2D plots of binding for ligands with the receptors were shown in (Figures 26-29), showing binding interaction sites of ligands with protein active sites of receptors. The HB plots that explained these interactions of ligands were shown in (Figures 30-33). Both estimated free energy of binding and interaction surface area revealed the most favored binding. The ligand which had more negative value of estimated free energy of binding represented more efficient binding. Based on data obtained from docking studies, it has been found that:

1. HCMPPA was the most efficient binding as it has the most negative value of estimated free energy of binding.

2. The order of best binding of ligands with antibacterial receptors (1xk6 and 6gyw) was found to be: HCMPPA > HCPA and this was congruent with experimental results.

3. A favorable interaction was shown between ligands and antibacterial receptors (1xk6 and 6gyw) than antifungal receptor (3ppc).

4. There was great interaction between ligands and receptor of Covid 19 (PDB code: 7jpy) so it is possible to use ligands for Covid 19 treatment.

\section{Conclusion}

Tellurite-pyridine $\mathrm{Cd}(\mathrm{II})$ complexes were synthesized and characterized by several advanced spectroscopic techniques. The data showthe mononegative bidentate behavior of igandgiving anionic tellurito complex with octahedral configuration around Cd(II). Also, the molecular modeling of all compounds accompanied by theoretical calculations were performed using DFT where, the outcome data showed a great compatibility with the experimental investigations. Cyclic voltammetry studies explained the influence of the ligands on the electrochemical behavior of Cd(II) in solution which observedin the change in values of different cyclic voltammetry characteristics ( $D, \mathrm{i}_{\mathrm{p}}, \mathrm{E}_{\mathrm{pc}}, \mathrm{E}_{\mathrm{pa}}$, $\mathrm{a}, \mathrm{k}_{\mathrm{s}}, \Gamma$ and $\left.\mathrm{Q}\right)$. The biological studies were screened and emphasized Cd(II) complexes exhibit higher protection against DNA damage, lower antimicrobial and higher antioxidant features than the parent pyridyl ligands.

\section{References}

[1] A.G. Pershina, A.E. Sazonov, D. V Novikov, A.S. Knyazev, T.I. Izaak, V.I. Itin, E.P. Naiden, A.A. Magaeva, O.G. Terechova, Study of DNA interaction with cobalt ferrite nanoparticles, J. Nanosci. Nanotechnol. 11(2011) 2673-2677. https://doi.org/10.1166/jnn.2011.2739

[2] M.N. Patel, C.R. Patel, H.N. Joshi, Metal-based biologically active compounds: synthesis, characterization, DNA interaction, antibacterial, cytotoxic and SOD mimic activities, Appl. Biochem. Biotechnol. 169(2013) 1329-1345.https://doi.org/10.1007/s12010-012-0086-x

[3]T. Suksrichavalita, S. Prachayasittikulb, C. Nantasenamata, C. Isarankura-Na-Ayudhyaa, V. Prachayasittikula, Copper complexes of pyridine derivatives with superoxide scavenging and antimicrobial activities, European Journal of Medicinal Chemistry. 44 (2009) 3259-

3265. https://doi.org/10.1016/j.ejmech.2009.03.033

[4] T.J. Hubin, P.N.-A. Amoyaw, K.D. Roewe, N.C. Simpson, R.D. Maples, T.N.C. Freeman, A.N. Cain, J.G. Le, S.J. Archibald, S.I. Khan, others, Synthesis and antimalarial activity of metal complexes of cross-bridged tetraazamacrocyclic ligands, Bioorg. Med. Chem. 22(2014) 3239-

3244. https://doi.org/10.1016/j.bmc.2014.05.003

[5] S.A. Khan, A.M. Asiri, K. Al-Amry, M.A. Malik, Synthesis, characterization, electrochemical studies, and in vitro antibacterial activity of novel thiosemicarbazone and its Cu (II), Ni (II), and Co (II) complexes, Sci. World J. (2014)1-9. https://doi.org/10.1155/2014/592375

[6] J.Deng, P.Yu,Z.Zhang,J.Wang,J. Cai, N.Wu, H.Sun, H.Liang,F.Yang, Designing anticancer copper(II) complexes by optimizing 2-pyridine-thiosemicarbazone ligands, European Journal of Medicinal Chemistry. 158 (2018) 442-452.https://doi.org/10.1016/j.ejmech.2018.09.020

[7] Z. Liu, I. Romero-Canelon, A. Habtemariam, G. J. Clarkson, P. J. Sadler, Potent Half-Sandwich Iridium(III) Anticancer Complexes Containing C^N-Chelated and Pyridine Ligands,

Organometallics. 33 (2014) 5324-53. https://doi.org/10.1021/om500644f

[8] M.Alinaghi,K.Karami,A.Shahpiri,A.Kazeminasab,A.A.Momtazi-Borojeni,E.Abdollahi,J.Lipkowski,A Pd(II) complex derived from pyridine-2-carbaldehyde oxime ligand: Synthesis, characterization, DNA and BSA interaction studies and in vitro anticancer activity. Journal of Molecular Structure. 1219 (2020) 128479. https://doi.org/10.1016/j.molstruc.2020.128479

[9] N.R.Palepu,J.R.Premkumar,A.K.Verma,K.Bhattacharjee,S.R.Joshi,S.Forbes,Y.Mozharivskyj,K.M.Rao, Antibacterial, in vitro antitumor activity and structural studies of rhodium and iridium complexes featuring the two positional isomers of pyridine carbaldehyde picolinic hydrazone ligand. Arabian Journal of Chemistry. 11 (2018) 714-728. https://doi.org/10.1016/j.arabjc.2015.10.011

[10] T.Sedaghat,R.Habibi,H.Motamedi,H. R.Khavasi,Synthesis, structural characterization and antibacterial activity of diorganotin(IV) complexes with ONO tridentate Schiff bases containing pyridine ring. Chinese Chemical Letters 23 (2012) 1355-1358. https://doi.org/10.1016/j.cclet.2012.10.010

[11] G. G.Mohamed,Z. H. AbdEl-Wahab, Mixed ligand complexes of bis(phenylimine) Schiff base ligands incorporating pyridinium moiety: Synthesis, characterization and antibacterial activity. Spectrochimica Acta Part A: Molecular and Biomolecular Spectroscopy. 61 (2005) 1059-

1068.https://doi.org/10.1016/j.saa.2004.06.021 
[12] A.Kantouch, A A.El-Sayed, Polyvinyl pyridine metal complex as permanent antimicrobial finishing for viscose fabric. International Journal of Biological Macromolecules. 43 (2008) 451-455. https://doi.org/10.1016/j.ijbiomac.2008.08.011

[13] E.K.Beloglazkina,D.D.Korablina,N.I.Vorozhtsov,L.A.Sviridova,A.A.Moiseeva,D. A.Skvortsov,V.B.Rybakov,A.G.Majouga,N.V.Zyk,Synthesis of 3-(pyridine-2yl)-4,5-dihydro-1 H-pyrazole-1-thiocarboxamides and their copper(II) complexes. Arabian Journal of Chemistry. 12 (2019) 1050-

1060. https://doi.org/10.1016/j.arabjc.2017.01.005

[14] A. Jarrahpour, D. Khalili, E. De Clercq, C. Salmi, J.M. Brunel, Synthesis, antibacterial, antifungal and antiviral activity evaluation of some new bis-Schiff bases of isatin and their derivatives, Molecules. 12(2007) 1720-1730. https://doi.org/10.3390/12081720

[15] J.R. Anacona, M. Rincones, Tridentate hydrazone metal complexes derived from cephalexin and 2-hydrazinopyridine: synthesis, characterization and antibacterial activity, Spectrochim. Acta Part A Mol. Biomol. Spectrosc. 141 (2015)169-175. https://doi.org/https://doi.org/10.1016/j.saa.2015.01.009

[16] J.R. Anacona, G. Calvo, J. Camus, Tetradentate hydrazone metal complexes derived from cefazolin and 2, 6-diacetylpyridine hydrazide: synthesis, characterization, and antibacterial activity, Monatshefte Für Chemie-Chemical Mon. 147 (2016)725-733.https://doi.org/10.1007/s00706-015-1585-6

[17] J. Anacona, J. Santaella, Synthesis, magnetic and spectroscopic studies of a Schiff base derived from cephaclor and 1, 2-diaminobenzene and its transition metal complexes, Spectrochim. Acta Part A Mol. Biomol. Spectrosc. 115(2013)800-804. https://doi.org/10.1016/j.saa.2013.06.107

[18] J.R. Anacona, J.L. Rodriguez, J. Camus, Synthesis, characterization and antibacterial activity of a Schiff base derived from cephalexin and sulphathiazole and its transition metal complexes, Spectrochim. Acta Part A Mol. Biomol. Spectrosc. 129 (2014)96-

102. https://doi.org/https://doi.org/10.1016/j.saa.2014.03.019

[19] N.Y. Gorobets, B.H. Yousefi, F. Belaj, C.O. Kappe, Rapid microwave-assisted solution phase synthesis of substituted 2-pyridone libraries, Tetrahedron. 60 (2004) 8633-8644.

[20] K. Madhavi, P. Sudeepthi, Synthesis of Cyanoacetylated Derivatives of Some Heteroaryl Amines as Analgesic and Antioxidant Agents, Int. J. Pharm. Sci. Nanotechnol. 5 (2013) 1879-1884.

[21]N.H. Metwally, F.M. Abdelrazek, S.M. Eldaly, P. Metz, 3-(3, 5-Dimethyl-1H-Pyrazol-1-yl)-3-Oxopropanenitrile as Precursor for Some New Mono-Heterocyclic and Bis-Heterocyclic Compounds, J. Heterocycl. Chem. 54 (2017) 289-294.

[22]A.A. Fadda, S. Bondock, R. Rabie, H.A. Etman, Cyanoacetamide derivatives as synthons in heterocyclic synthesis, Turkish J. Chem. 32 (2008) $259-286$.

[23]A.A. Fadda, R. Rabie, Cyanoacetylation of amines: recent advances in preparation methods and their synthetic uses in the formation of biologically active compounds, Res. Chem. Intermed. 42 (2016) 771-811.

[24] V.D. Dyachenko, R.P. Tkachiov, O.S. Bityukova, Chemical properties of cyanoacetanilides and synthesis of biologically active compounds around them, Russ. J. Org. Chem. 44 (2008) 1565.

[25] R.E. Khidre, I.A.M. Radini, D.A. Ibrahim, Design and synthesis of some new thiophene and 1, 3, 4-thiadiazole based heterocycles, Phosphorus. Sulfur. Silicon Relat. Elem. 194 (2019) 1040-1047.

[26] A.M. Farag, N.A. Kheder, K.M. Dawood, Efficient Syntheses of Some New Pyridine Based Heterocycles, Effic. Synth. Some New Pyridine Based Heterocycles. 2 (2013) 26-39.

[27] J.H. Al-Fahemi, M. Abdallah, E.A.M. Gad, B. Jahdaly, Experimental and theoretical approach studies for melatonin drug as safely corrosion inhibitors for carbon steel using DFT, J. Mol. Liq. 222 (2016) 1157-1163.

[28] Ö. Tamer, D. Avcli, N. Dege, Y. Atalay, Synthesis, crystal structure, photophysical properties, density functional theory calculations and molecular docking studies on Cd (II) complex of 4, 4'-dimethyl-2, 2'-dipyridyl, J. Mol. Struct. 1202 (2020) 127288.

[29] M. Frisch, G.W. Trucks, H.B. Schlegel, G.E. Scuseria, M.A. Robb, J.R. Cheeseman, G. Scalmani, V. Barone, B. Mennucci, Ga. Petersson, others, gaussian 09, Revision d. 01, Gaussian, Inc., Wallingford CT. 201 (2009)150-166.

[30]M.A.I. Salem, M.I. Marzouk, A.M. El-Kazak, Synthesis and characterization of some new coumarins with in vitro antitumor and antioxidant activity and high protective effects against DNA damage, Molecules. 21 (2016) 249. https://doi.org/10.3390/molecules21020249

[31] M.A. Diab, G.G. Mohamed, W.H. Mahmoud, A.Z. El-Sonbati, S.M. Morgan, S.Y. Abbas, Inner metal complexes of tetradentate Schiff base: Synthesis, characterization, biological activity and molecular docking studies, Appl. Organomet. Chem. 33 (2019) e4945.

[32] 00G.M. Morris, D.S. Goodsell, R.S. Halliday, R. Huey, W.E. Hart, R.K. Belew, A.J. Olson, Automated docking using a Lamarckian genetic algorithm and an empirical binding free energy function, J. Comput. Chem. 19 (1998) 1639-1662.

[33]R. Huey, G.M. Morris, A.J. Olson, D.S. Goodsell, A semiempirical free energy force field with charge-based desolvation, J. Comput. Chem. 28 (2007) 11451152. 
[34] Z. Bikadi, E. Hazai, Application of the PM6 semi-empirical method to modeling proteins enhances docking accuracy of AutoDock, J. Cheminform. 1 (2009) $1-16$.

[35] K.M. Ibrahim, I.M. Gabr, G.M.A. El-Reash, R.R. Zaky, Spectral, magnetic, thermal, antimicrobial, and eukaryotic DNA studies on acetone [N-(3-hydroxy-2naphthoyl)] hydrazone complexes, Monatshefte Für Chemie-Chemical Mon. 140 (2009) 625-632.

[36] H. Tan, P. Kong, R. Zhang, M. Gao, M. Liu, X. Gu, W. Liu, Z. Zheng, Controllable Generation of Reactive Oxygen Species on Cyano-Group-Modified Carbon Nitride for Selective Epoxidation of Styrene, Innov. 2 (2021) 100089.

[37]M.A. Diab, A.Z. El-Sonbati, S.M. Morgan, M.A. El-Mogazy, Polymer complexes. LXXI. Spectroscopic studies, thermal properties, DNA binding and antimicrobial activity of polymer complexes, Appl. Organomet. Chem. 32 (2018) e4378.

[38]T.A. Yousef, G.M.A. El-Reash, O.A. El-Gammal, R.A. Bedier, Synthesis, characterization, optical band gap, in vitro antimicrobial activity and DNA cleavage studies of some metal complexes of pyridyl thiosemicarbazone, J. Mol. Struct. 1035 (2013) 307-317.

[39]O.A. El-Gammal, G.M.A. El-Reash, S.E. Ghazy, A.H. Radwan, Synthesis, characterization, molecular modeling and antioxidant activity of (1E, 5E)-1, 5-bis (1(pyridin-2-yl) ethylidene) carbonohydrazide (H2APC) and its zinc (II), cadmium (II) and mercury (II) complexes, J. Mol. Struct. 1020 (2012) 6-15.

[40] R.R. Zaky, K.M. Ibrahim, I.M. Gabr, Bivalent transition metal complexes of o-hydroxyacetophenone [N-(3-hydroxy-2-naphthoyl)] hydrazone: Spectroscopic, antibacterial, antifungal activity and thermogravimetric studies, Spectrochim. Acta Part A Mol. Biomol. Spectrosc. 81 (2011) $28-34$.

[41]S.M. Morgan, A.Z. El-Sonbati, H.R. Eissa, Geometrical structures, thermal properties and spectroscopic studies of Schiff base complexes: Correlation between ionic radius of metal complexes and DNA binding, J. Mol. Liq. 240 (2017) 752-776.

[42] H. Mansuri-Torshizi, R. Mital, T.S. Srivastava, H. Parekh, M.P. Chitnis, Synthesis, characterization, and cytotoxic studies of a-diimine/1, 2-diamine platinum (II) and palladium (II) complexes of selenite and tellurite and binding of some of these complexes to DNA, J. Inorg. Biochem. 44 (1991) $239-247$.

[43] I.C. Pirmettis, M.S. Papadopoulos, S.G. Mastrostamatis, C.P. Raptopoulou, A. Terzis, E. Chiotellis, Synthesis and characterization of oxotechnetium (V) mixed-ligand complexes containing a tridentate N-substituted bis (2-mercaptoethyl) amine and a monodentate thiol, Inorg. Chem. 35 (1996) $1685-1691$.

[44]A.Z. El-Sonbati, M.A. Diab, A.M. Eldesoky, S.M. Morgan, O.L. Salem, Polymer complexes. LXXVI. Synthesis, characterization, CT-DNA binding, molecular docking and thermal studies of sulfoxine polymer complexes, Appl. Organomet. Chem. 33 (2019) e4839.

[45]A.A. Fahem, Comparative studies of mononuclear Ni (II) and UO2 (II) complexes having bifunctional coordinated groups: synthesis, thermal analysis, X-ray diffraction, surface morphology studies and biological evaluation, Spectrochim. Acta Part A Mol. Biomol. Spectrosc. 88 (2012) 10-

22. https://doi.org/10.1016/j.saa.2011.11.037

[46]R.R. da Silva, T.C. Ramalho, J.M. Santos, J.D. Figueroa-Villar, On the limits of highest-occupied molecular orbital driven reactions: the frontier effective-forreaction molecular orbital concept, J. Phys. Chem. A. 110 (2006) 1031-1040. https://doi.org/10.1021/jp054434y

[47] R. Zaky, A. Fekri, Structural, spectral and DFT studies of N-ethyl-2-(4-(phenylamino)-4-thioxobutan-2-ylidene) hydrazinecarbothioamide complexes synthesized by ball milling, J. Mol. Struct. 1079 (2015) 203-213. https://doi.org/10.1016/j.molstruc.2014.09.033

[48] E. Gileadi, Electrode kinetics for chemists, chemical engineers, and materials scientists, Capstone, 98 (1994) 644-

645. https://doi.org/10.1002/bbpc.19940980425

[49] A. Khan, R. Ahmed, M. Mirza, Evaluation of kinetic parameters of uranyl acetate complexes in ethanolic solution by cyclic voltammetry, J. Radioanal. Nucl. Chem. 283 (2010) 527-531. https://doi.org/10.1007/s10967-009-0372-4

[50] C.H. Bamford, R.G. Compton, J.D.R. Thomas, Electrode kinetics: principles and methodology. 26 (1986). (ISBN 0-444-42550-0).

[51] J.C. Hidalgo-Acosta, V. Climent, M.F. Suárez-Herrera, J.M. Feliu, Enhanced electrochemical reversibility of ultrathin aniline oligomer films grown on Pt (111), Electrochem. Commun. 13 (2011) 1304-1308. https://doi.org/10.1016/j.elecom.2011.07.021

[52] W. Ong, A.E. Kaifer, Unusual electrochemical properties of unsymmetric viologen dendrimers, J. Am. Chem. Soc. 124 (2002) 93589359. https://doi.org/10.1021/ja0268231

[53] D.K. Gosser, Cyclic voltammetry: simulation and analysis of reaction mechanisms, VCH New York. 24 (1994) 1237-

1238.https://doi.org/10.1080/00945719408001398

[54] S.E. El-Shereafy, E.A. Gomaa, A.M. Yousif, A.S.A. El-Yazed, Electrochemical and Thermodynamic Estimations of the Interaction Parameters for Bulk and Nano-Silver Nitrate (NSN) with Cefdinir Drug Using a Glassy Carbon Electrode, Iran. J. Mater. Sci. Eng. 14 (2017) 48-57. https://doi.org/10.22068/ijmse.14.4.48

[55]S. Shaaban, A. Negm, M.A. Sobh, L.A. Wessjohann, Organoselenocyanates and symmetrical diselenides redox modulators: design, synthesis and biological evaluation, Eur. J. Med. Chem. 2015, 97, 190-201. https://doi.org/10.1016/j.ejmech.2015.05.002 
[56] R. Shah, A. Alharbi, A.M. Hameed, F. Saad, R. Zaky, A.M. Khedr, N. El-Metwaly, Synthesis and Structural Elucidation for New Schiff Base Complexes; Conductance, Conformational, MOE-Docking and Biological Studies, J. Inorg. Organomet. Polym. Mater. (2020) 1-13.

[57] I. Kostova, L. Saso, Advances in research of Schiff-base metal complexes as potent antioxidants,Curr.Med.Chem. 2013, 20(36), 4609-4632. DOI : 10.2174/09298673113209990149

[58] T.Mosmann,J. Immunol. Methods 65 (1983) 55-63.https://doi.org/10.1016/0022-1759(83)90303-4

[59]A. Rambabu, M. Pradeep Kumar, N. Ganji, S. Daravath, Shivaraj, DNA binding and cleavage, cytotoxicity and antimicrobial studies of Co (II), Ni (II), Cu (II) and Zn (II) complexes of 1-((E)-(4-(trifluoromethoxy) phenylimino) methyl) naphthalen-2-ol Schiff base, J. Biomol. Struct. Dyn. 38 (2020) 307-

316. https://doi.org/10.1080/07391102.2019.1571945

\section{Tables}

Table 1: Analytical and physical data of HCPA and its Cd(II) complex

\begin{tabular}{|c|c|c|c|c|c|c|c|c|}
\hline \multirow[t]{2}{*}{ Compound } & \multirow{2}{*}{$\begin{array}{l}\text { Empirical Formula } \\
\text { (M.Wt.) }\end{array}$} & \multirow[t]{2}{*}{ Color } & \multirow{2}{*}{$\begin{array}{l}\text { M.P. } \\
\left({ }^{\circ} \mathrm{C}\right)\end{array}$} & \multicolumn{5}{|c|}{ \%Found (Calculated) } \\
\hline & & & & $\% \mathrm{C}$ & $\% \mathrm{H}$ & $\% \mathrm{~N}$ & $\% \mathrm{Cd}$ & $\% \mathrm{Cl}^{-}$ \\
\hline HCPA & $\begin{array}{l}\mathrm{C}_{8} \mathrm{H}_{7} \mathrm{~N}_{3} \mathrm{O} \\
(161.1641)\end{array}$ & Yellow & 150 & $\begin{array}{l}59.45 \\
(59.62)\end{array}$ & $\begin{array}{l}4.31 \\
(4.38)\end{array}$ & $\begin{array}{l}25.96 \\
(26.07)\end{array}$ & - & - \\
\hline $\mathrm{Na}_{2}\left[\mathrm{Cd}(\mathrm{CPA})\left(\mathrm{TeO}_{3}\right)\left(\mathrm{H}_{2} \mathrm{O}\right) \mathrm{Cl}\right] \cdot 2 \mathrm{H}_{2} \mathrm{O}$ & $\begin{array}{l}\mathrm{Na}_{2} \mathrm{CdTeC}_{8} \mathrm{H}_{12} \mathrm{~N}_{3} \mathrm{O}_{7} \mathrm{Cl} \\
(583.6477)\end{array}$ & White & $>300$ & $\begin{array}{l}16.39 \\
(16.46)\end{array}$ & $\begin{array}{l}2.05 \\
(2.07)\end{array}$ & $\begin{array}{l}7.13 \\
(7.2)\end{array}$ & $\begin{array}{l}19.21 \\
(19.26)\end{array}$ & $\begin{array}{l}6.01 \\
(6.07)\end{array}$ \\
\hline
\end{tabular}

Table 2: Analytical and physical data of HCMPPA and its Cd(II) complex

\begin{tabular}{|c|c|c|c|c|c|c|c|c|}
\hline \multirow[t]{2}{*}{ Compound } & \multirow{2}{*}{$\begin{array}{l}\text { Empirical Formula } \\
\text { (M.Wt.) }\end{array}$} & \multirow[t]{2}{*}{ Color } & \multirow{2}{*}{$\begin{array}{l}\text { M.P. } \\
\left({ }^{\circ} \mathrm{C}\right)\end{array}$} & \multicolumn{5}{|c|}{ \%Found (Calculated) } \\
\hline & & & & $\% \mathrm{C}$ & $\% \mathrm{H}$ & $\% \mathrm{~N}$ & $\% \mathrm{Cd}$ & $\% \mathrm{Cl}^{-}$ \\
\hline HCMPPA & $\begin{array}{l}\mathrm{C}_{15} \mathrm{H}_{12} \mathrm{~N}_{4} \mathrm{OS} \\
(296.3528)\end{array}$ & Orange & $180-185$ & $\begin{array}{l}60.72 \\
(60.79)\end{array}$ & $\begin{array}{l}4.05 \\
(4.08)\end{array}$ & $\begin{array}{l}18.85 \\
(18.91)\end{array}$ & - & - \\
\hline $\mathrm{Na}_{2}\left[\mathrm{Cd}(\mathrm{CMPPA})\left(\mathrm{TeO}_{3}\right)\left(\mathrm{H}_{2} \mathrm{O}\right) \mathrm{Cl}\right] \cdot 2 \mathrm{H}_{2} \mathrm{O}$ & $\begin{array}{l}\mathrm{Na}_{2} \mathrm{CdTeC}_{15} \mathrm{H}_{17} \mathrm{~N}_{4} \mathrm{O}_{7} \mathrm{SCl} \\
(718.8364)\end{array}$ & Dark green & $>300$ & $\begin{array}{l}24.97 \\
(25.06)\end{array}$ & $\begin{array}{l}2.35 \\
(2.38)\end{array}$ & $\begin{array}{l}7.71 \\
(7.79)\end{array}$ & $\begin{array}{l}15.58 \\
(15.64)\end{array}$ & $\begin{array}{l}4.86 \\
(4.93)\end{array}$ \\
\hline
\end{tabular}

Table 3: Most important IR spectral bands of HCPA and its Cd(II) complex

\begin{tabular}{lllllllll} 
Compound & $\mathrm{u}(\mathrm{C}=\mathrm{N})_{\mathrm{py}}$ & $\mathrm{u}(\mathrm{C}=0)$ & $\mathrm{u}(\mathrm{C}=\mathrm{N})$ & $\mathrm{u}(\mathrm{C}-\mathrm{O})$ & $\mathrm{u}(\mathrm{C}=\mathrm{C})$ & $\mathrm{u}(\mathrm{Cd}-\mathrm{O})$ & $\mathrm{u}(\mathrm{Cd}-\mathrm{N})$ & $\mathrm{u}(\mathrm{Te}-\mathrm{O})$ \\
\hline $\mathrm{HCPA}$ & 1635 & 1672 & 2257 & - & - & - & - & - \\
\hline $\mathrm{Na}_{2}\left[\mathrm{Cd}(\mathrm{CPA})\left(\mathrm{TeO}_{3}\right)\left(\mathrm{H}_{2} \mathrm{O}\right) \mathrm{Cl}\right] .2 \mathrm{H}_{2} \mathrm{O}$ & 1624 & diss & 2260 & 1265 & 1633 & 525 & 422 & 677
\end{tabular}

Table 4: Most important IR spectral bands of HCMPPA and itsCd(II) complex

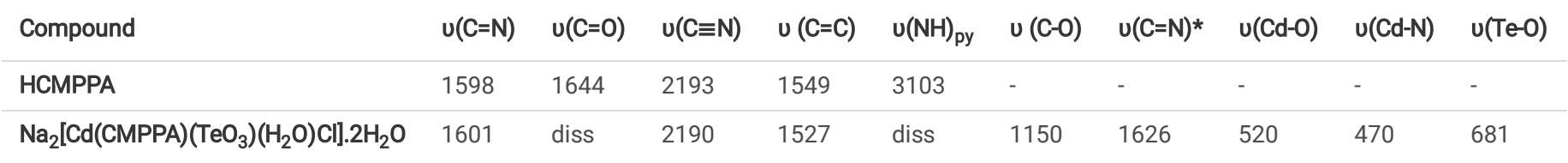


Table 5: The magnitudes of Lattice parameters and the particle size of $\mathrm{Na}_{2}\left[\mathrm{Cd}(\mathrm{CPA})\left(\mathrm{TeO}_{3}\right)\left(\mathrm{H}_{2} \mathrm{O}\right) \mathrm{Cl}\right] .2 \mathrm{H}_{2} \mathrm{O}$ complex

\begin{tabular}{|llllll|}
\hline Compound & $\boldsymbol{\theta}$ & $\mathrm{d}$ & $\boldsymbol{\beta}$ & $\mathrm{I}$ & $\mathrm{S}$ \\
& $(\mathrm{deg})$ & $(\AA)$ & $(\mathrm{deg})$ & $($ Counts $)$ & $(\mathrm{nm})$ \\
\hline $\mathrm{Na}_{2}\left[\mathrm{Cd}(\mathrm{CPA})\left(\mathrm{TeO}_{3}\right)\left(\mathrm{H}_{2} \mathrm{O}\right) \mathrm{Cl}\right] .2 \mathrm{H}_{2} \mathrm{O}$ & 18.82 & 2.39 & 0.199 & 76 & 0.769 \\
\hline
\end{tabular}

Table 6: Calculated quantum chemical parameters for HCPA and its Cd(II) complex

\begin{tabular}{|c|c|c|}
\hline \multicolumn{3}{|l|}{ Theoretical data } \\
\hline & HCPA & $\mathrm{Na}_{2}\left[\mathrm{Cd}(\mathrm{CPA})\left(\mathrm{TeO}_{3}\right)\left(\mathrm{H}_{2} \mathrm{O}\right) \mathrm{Cl}\right] \cdot 2 \mathrm{H}_{2} \mathrm{O}$ \\
\hline $\mathrm{E}_{\text {номо }}(\mathrm{eV})$ & -7.1835 & -6.7941 \\
\hline $\mathrm{E}_{\text {LUMO }} \quad(\mathrm{eV})$ & -1.7954 & -2.5747 \\
\hline$E_{\text {gap }} \quad(e V)$ & -5.3881 & -4.2194 \\
\hline I $\quad(e V)$ & 7.1835 & 6.7941 \\
\hline $\mathrm{A}(\mathrm{eV})$ & 1.7954 & 2.5747 \\
\hline$x \quad(e V)$ & 4.4895 & 4.6844 \\
\hline$\mu \quad(\mathrm{eV})$ & -4.4895 & -4.6844 \\
\hline$\eta(\mathrm{eV})$ & 2.6941 & 2.1097 \\
\hline $\mathrm{S} \quad\left(\mathrm{eV}^{-1}\right)$ & 0.1856 & 0.237 \\
\hline$\omega(\mathrm{eV})$ & 3.7407 & 5.2007 \\
\hline Total energy (eV) & -14930.62 & -25063.76 \\
\hline Dipole moment (Debye) & 8.8105 & 7.4188 \\
\hline
\end{tabular}

Table 7:Calculated quantum chemical parameters for HCMPPA and its Cd(II) complex

\begin{tabular}{|c|c|c|}
\hline \multicolumn{3}{|l|}{ Theoretical data } \\
\hline & HCMPPA & $\mathrm{Na}_{2}\left[\mathrm{Cd}(\mathrm{CMPPA})\left(\mathrm{TeO}_{3}\right)\left(\mathrm{H}_{2} \mathrm{O}\right) \mathrm{Cl}\right] \cdot 2 \mathrm{H}_{2} \mathrm{O}$ \\
\hline $\mathrm{E}_{\text {номо }}(\mathrm{eV})$ & -6.4543 & -6.0145 \\
\hline $\mathrm{E}_{\text {LUMO }} \quad(\mathrm{eV})$ & -2.1288 & -4.8654 \\
\hline$E_{\text {gap }} \quad(e V)$ & -4.3255 & -1.1491 \\
\hline $\mathrm{I} \quad(\mathrm{eV})$ & 6.4543 & 6.0145 \\
\hline A $(e V)$ & 2.1288 & 4.8654 \\
\hline$x \quad(e V)$ & 4.2916 & 5.4399 \\
\hline$\mu \quad(\mathrm{eV})$ & -4.2916 & -5.4399 \\
\hline$\eta(\mathrm{eV})$ & 2.1628 & 0.5746 \\
\hline $\mathrm{S}\left(\mathrm{eV}^{-1}\right)$ & 0.2312 & 0.8703 \\
\hline$\omega(\mathrm{eV})$ & 4.2579 & 25.7528 \\
\hline Total energy (eV) & -34599.02 & -34163.64 \\
\hline Dipole moment (Debye) & 9.0048 & 7.7125 \\
\hline
\end{tabular}




\begin{tabular}{|c|c|c|c|c|c|c|c|c|c|c|c|c|c|c|}
\hline $\begin{array}{l}M \times 10^{6} \\
\left(\mathrm{~mol} / \mathrm{cm}^{3}\right)\end{array}$ & $\begin{array}{l}\text { Epa } \\
\text { (volt) }\end{array}$ & $\begin{array}{l}\text { Epc } \\
\text { (volt) }\end{array}$ & $\begin{array}{l}\Delta \text { Ep } \\
\text { (volt) }\end{array}$ & $\begin{array}{l}- \\
\text { Ipax104 } \\
\text { (Amp) }\end{array}$ & $\begin{array}{l}\text { Ipcx104 } \\
\text { (Amp) }\end{array}$ & $\begin{array}{l}\text { Ipa/ } \\
\text { lpc (Amp) }\end{array}$ & $E^{\circ}$ & $\begin{array}{l}\mathrm{Da} \\
\mathrm{x} 10^{4} \\
\left(\mathrm{~cm}^{2} / \mathrm{s}\right)\end{array}$ & $\begin{array}{l}\mathrm{Dc} \\
\mathrm{x} 10^{4} \\
\left(\mathrm{~cm}^{2} / \mathrm{s}\right)\end{array}$ & $a n_{a}$ & $\begin{array}{l}\mathrm{Ks} \\
(\mathrm{cm} / \mathrm{s})\end{array}$ & $\begin{array}{l}\Gamma \mathrm{c} \\
\mathrm{x} 10^{8} \\
(\mathrm{~mol} / \\
\left.\mathrm{cm}^{2}\right)\end{array}$ & $\begin{array}{l}(+) \\
Q c \\
\times 10^{4}\end{array}$ & Г \\
\hline 0.99 & -0.6507 & -0.9235 & 0.2728 & 1.19 & 1.82 & 0.656 & -0.7871 & 2.574 & 5.99 & 0.6964 & 16.8 & 1.5578 & 0.944 & 1 \\
\hline 1.32 & -0.6362 & -0.9257 & 0.2895 & 1.77 & 2.34 & 0.757 & -0.7809 & 3.212 & 5.60 & 0.6374 & 21.4 & 2.003 & 1.21 & 1 \\
\hline 1.64 & -0.5826 & -0.8698 & 0.2872 & 4.46 & 2.76 & 1.618 & -0.7262 & 13.145 & 5.02 & 0.8239 & 22.0 & 2.3617 & 1.43 & 3 \\
\hline
\end{tabular}

Table 9: Solvation and cyclic voltammetric parameters of $\mathrm{CdCl}_{2}$ in the presence of $\mathrm{HCPA}$ at $301.15 \mathrm{~K}$ and scan rate $0.1 \mathrm{~V} / \mathrm{s}$

\begin{tabular}{|c|c|c|c|c|c|c|c|c|c|c|c|c|c|c|}
\hline $\begin{array}{l}\mathrm{Mx} 10^{6} \\
\left(\mathrm{~mol} / \mathrm{cm}^{3}\right)\end{array}$ & $\begin{array}{l}\text { Epa } \\
\text { (volt) }\end{array}$ & $\begin{array}{l}\text { Epc } \\
\text { (volt) }\end{array}$ & $\begin{array}{l}\Delta \text { Ep } \\
\text { (volt) }\end{array}$ & $\begin{array}{l}\text { Ipax10 } \\
\text { (Amp) }\end{array}$ & $\begin{array}{l}\text { Ipcx104 } \\
\text { (Amp) }\end{array}$ & $\begin{array}{l}\text { Ipa/ } \\
\text { Ipc (Amp) }\end{array}$ & $E^{\circ}$ & $\begin{array}{l}\mathrm{Da} \\
\mathrm{x} 10^{4} \\
\left(\mathrm{~cm}^{2} / \mathrm{s}\right)\end{array}$ & $\begin{array}{l}\text { Dc } \\
\times 10^{4} \\
\left(\mathrm{~cm}^{2} / \mathrm{s}\right)\end{array}$ & $a n_{a}$ & $\begin{array}{l}\text { Ks } \\
(\mathrm{cm} / \mathrm{s})\end{array}$ & $\begin{array}{l}\Gamma \mathrm{c} \\
\mathrm{x} 10^{8} \\
(\mathrm{~mol} / \\
\left.\mathrm{cm}^{2}\right)\end{array}$ & $\begin{array}{l}(+) \\
Q c \\
\times 10^{4}\end{array}$ & $\begin{array}{l}\Gamma \hat{\varepsilon} \\
\mathrm{x} 1\end{array}$ \\
\hline 0.327 & -0.5776 & -0.8725 & 0.2949 & 4.42 & 2.98 & 1.4852 & -0.7251 & 13.0 & 5.89 & 0.814 & 27.5 & 2.5509 & 1.55 & 3. \\
\hline 0.651 & -0.5783 & -0.8746 & 0.2963 & 4.10 & 2.91 & 1.4105 & -0.7265 & 11.3 & 5.65 & 0.8746 & 28.7 & 2.4904 & 1.51 & 3. \\
\hline 0.974 & -0.5738 & -0.8844 & 0.3106 & 4.38 & 2.84 & 1.5432 & -0.7291 & 12.9 & 5.43 & 0.8850 & 37.3 & 2.4319 & 1.47 & 3. \\
\hline 1.29 & -0.5714 & -0.8956 & 0.3242 & 3.95 & 2.76 & 1.4309 & -0.7335 & 10.6 & 5.17 & 0.8366 & 45.9 & 2.3649 & 1.43 & $3 .:$ \\
\hline 1.61 & -0.5696 & -0.9038 & 0.3342 & 2.61 & 2.61 & 0.998 & -0.7367 & 4.64 & 4.66 & 0.8168 & 52.2 & 2.2378 & 1.36 & $2 .:$ \\
\hline
\end{tabular}

Table 10:The stability constant for the $\left(\mathrm{Cd}^{2+} / \mathrm{HCPA}\right)$ complex at $301.15 \mathrm{~K}$

\begin{tabular}{|llllllll|}
\hline $\begin{array}{l}{[\mathrm{M}] \times 10^{6}} \\
\left(\mathrm{~mol} / \mathrm{cm}^{3}\right)\end{array}$ & $\begin{array}{l}{[\mathrm{L}] \times 10^{6}} \\
\left(\mathrm{~mol} / \mathrm{cm}^{3}\right)\end{array}$ & $\begin{array}{l}\left(E^{\circ}\right)_{M} \\
(\text { volt })\end{array}$ & $\begin{array}{l}\left(E^{\circ}\right)_{C} \\
(\text { volt })\end{array}$ & $\Delta E($ volt $)$ & $\log [\mathrm{L}]$ & $\log \beta_{M x}$ & $\Delta G(\mathrm{~kJ} / \mathrm{mol})$ \\
\hline 1.63 & 0.327 & -0.7262 & -0.7251 & -0.00115 & -6.4857 & 1.2587 & -7.2576 \\
\hline 1.63 & 0.651 & -0.7262 & -0.7265 & 0.00025 & -6.1861 & 2.4828 & -14.3163 \\
\hline 1.62 & 0.974 & -0.7262 & -0.7291 & 0.0029 & -6.0114 & 3.7059 & -20.9409 \\
\hline 1.62 & 1.29 & -0.7262 & -0.7335 & 0.0073 & -5.8879 & 4.9546 & -28.5692 \\
\hline 1.61 & 1.61 & -0.7262 & -0.7367 & 0.0105 & -5.7924 & 6.1438 & -35.4261 \\
\hline
\end{tabular}

Table 11: Energy values obtained in docking calculations of ligands (HCPA and HCMPPA) with receptor of Escherichia coli (PDB code: 1xk6).

\begin{tabular}{|c|c|c|c|c|c|c|}
\hline Ligand & $\begin{array}{l}\text { Est. Free Energy of } \\
\text { Binding (kcal/mol) }\end{array}$ & $\begin{array}{l}\text { Est. Inhibition } \\
\text { Constant }\left(\mathrm{K}_{\mathbf{i}}\right)(\boldsymbol{\mu} \mathrm{M})\end{array}$ & $\begin{array}{l}\text { vdW+ Hbond + desolv } \\
\text { Energy }(\mathrm{kcal} / \mathrm{mol})\end{array}$ & $\begin{array}{l}\text { Electrostatic Energy } \\
\text { (kcal/mol) }\end{array}$ & $\begin{array}{l}\text { Total } \\
\text { Intermolec. } \\
\text { Energy }\end{array}$ & $\begin{array}{l}\text { Interact. } \\
\text { Surface }\end{array}$ \\
\hline HCPA & -5.33 & 123.09 & -0.19 & & -6.25 & 500.934 \\
\hline HCMPPA & -8.9 & 299.09 & -1.19 & & -9.86 & 809.322 \\
\hline
\end{tabular}

Table 12: Energy values obtained in docking calculations of ligands (HCPA and HCMPPA) with receptor of Staphylococcus aureus (PDB code: 6 gyw). 


\begin{tabular}{|c|c|c|c|c|c|c|c|}
\hline Ligand & $\begin{array}{l}\text { Est. Free Energy of } \\
\text { Binding (kcal/mol) }\end{array}$ & & $\begin{array}{l}\text { Est. Inhibition } \\
\text { Constant }\left(\mathrm{K}_{\mathbf{i}}\right)(\boldsymbol{\mu} \mathrm{M})\end{array}$ & $\begin{array}{l}\text { vdW+ Hbond + desolv } \\
\text { Energy }(\mathrm{kcal} / \mathrm{mol})\end{array}$ & $\begin{array}{l}\text { Electrostatic Energy } \\
\text { (kcal/mol) }\end{array}$ & $\begin{array}{l}\text { Total } \\
\text { Intermolec. } \\
\text { Energy }\end{array}$ & $\begin{array}{l}\text { Interact. } \\
\text { Surface }\end{array}$ \\
\hline HCPA & -4.45 & 548.77 & -5.20 & -0.17 & -5.37 & & 421.064 \\
\hline HCMPPA & -6.75 & 11.36 & -6.19 & -1.12 & -7.32 & & 564.898 \\
\hline
\end{tabular}

Table 13: Energy values obtained in docking calculations of ligands (HCPA and HCMPPA) with receptor of Candida albicans (PDB code: 3ppc).

\begin{tabular}{|llllll|}
\hline Ligand & $\begin{array}{l}\text { Est. Free Energy of } \\
\text { Binding }(\mathrm{kcal} / \mathrm{mol})\end{array}$ & $\begin{array}{l}\text { Est. Inhibition } \\
\text { Constant }\left(\mathrm{K}_{\mathbf{i}}\right)(\mu \mathrm{M})\end{array}$ & $\begin{array}{l}\text { vdW+ Hbond + desolv } \\
\text { Energy }(\mathrm{kcal} / \mathrm{mol})\end{array}$ & $\begin{array}{l}\text { Electrostatic Energy } \\
(\mathrm{kcal} / \mathrm{mol})\end{array}$ & $\begin{array}{l}\text { Total } \\
\text { Intermolec. } \\
\text { Energy }\end{array}$ \\
\hline HCPA & -5.25 & 141.10 & -6.11 & -0.04 & $-\begin{array}{l}\text { Interact. } \\
\text { Surface }\end{array}$ \\
\hline HCMPPA & -4.45 & 103.10 & -5.10 & +0.42 & -6.14 \\
\hline
\end{tabular}

Table 14: Energy values obtained in docking calculations of ligands (HCPA and HCMPPA) with receptor of Covid 19(PDB code: 7jpy).

\begin{tabular}{|llllll|}
\hline Ligand & $\begin{array}{l}\text { Est. Free Energy of } \\
\text { Binding }(\mathrm{kcal} / \mathrm{mol})\end{array}$ & $\begin{array}{l}\text { Est. Inhibition } \\
\text { Constant }\left(\mathrm{K}_{\mathrm{i}}\right)(\boldsymbol{\mu})\end{array}$ & $\begin{array}{l}\text { vdW+ Hbond + desolv } \\
\text { Energy (kcal/mol) }\end{array}$ & $\begin{array}{l}\text { Electrostatic Energy } \\
(\mathrm{kcal} / \mathrm{mol})\end{array}$ & $\begin{array}{l}\text { Total } \\
\text { Intermolec. } \\
\text { Energy }\end{array}$ \\
\hline HCPA & -4.61 & 418.43 & -5.31 & -0.19 & $-\begin{array}{l}\text { Interact. } \\
\text { Surface }\end{array}$ \\
\hline HCMPPA & -6.33 & 24.87 & -6.21 & -0.73 & 479.486 \\
\hline
\end{tabular}

\section{Scheme}

Please see the Supplementary Files for the Scheme 1, 2, 3 and 4.

\section{Figures}




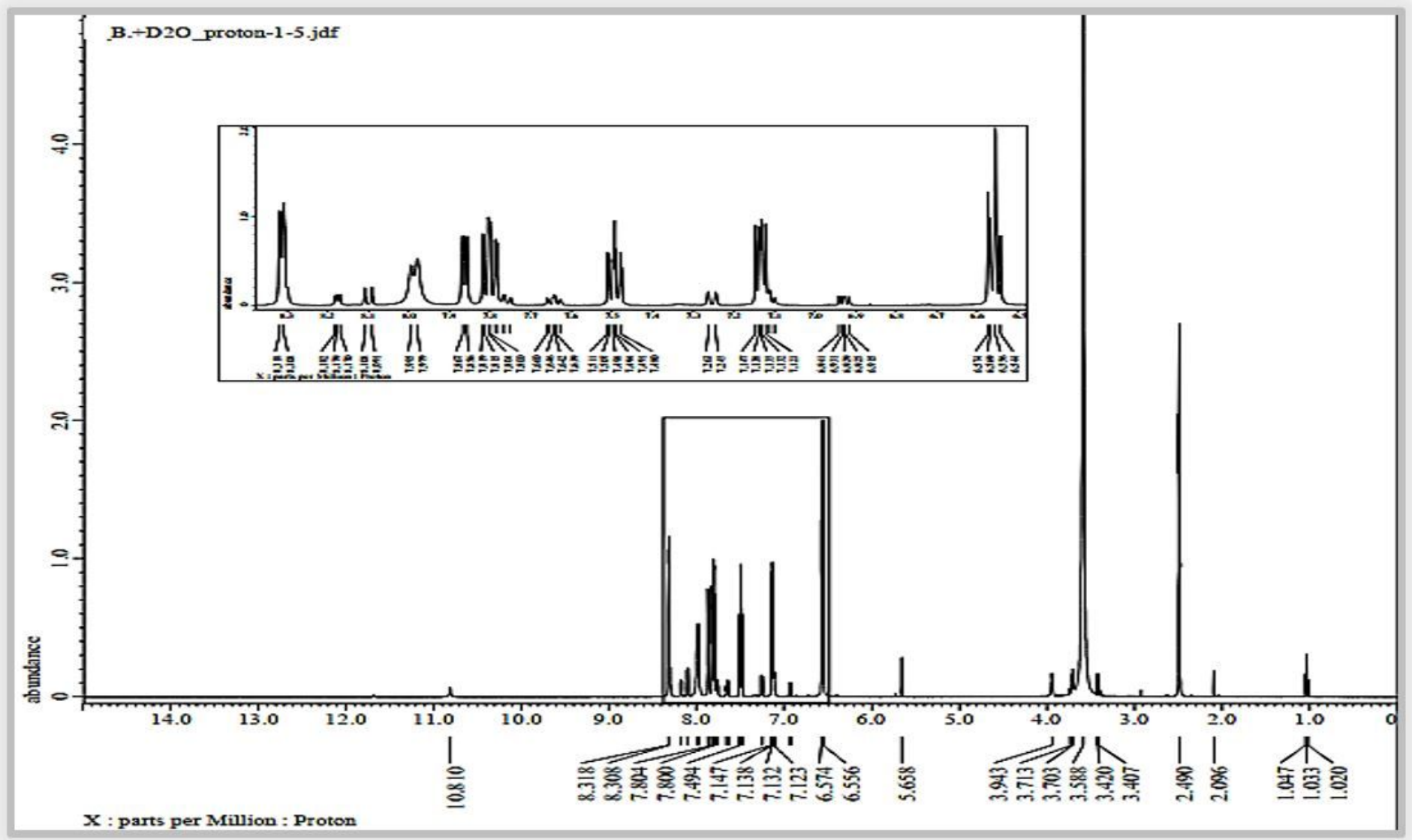

Figure 1

${ }^{1} \mathrm{H}$ NMR spectra of HCPA ligand 
(A)

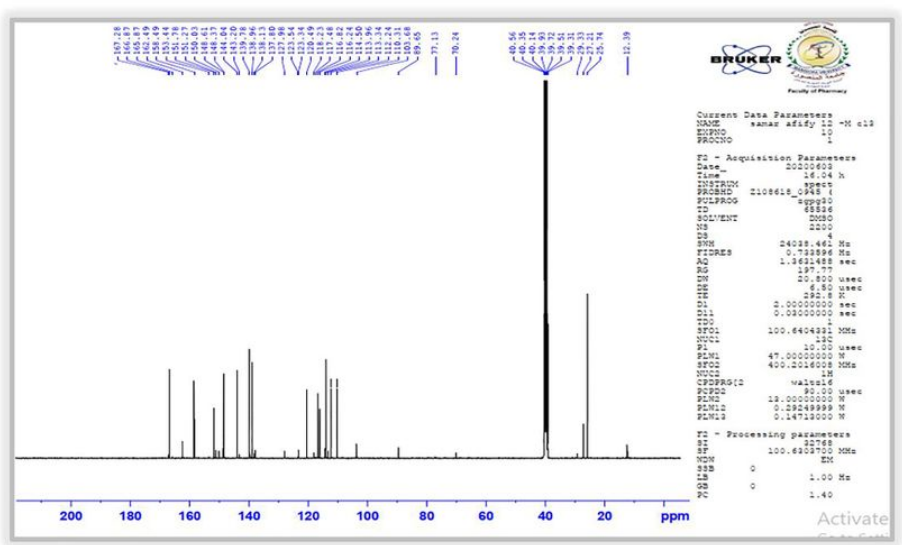

(B)

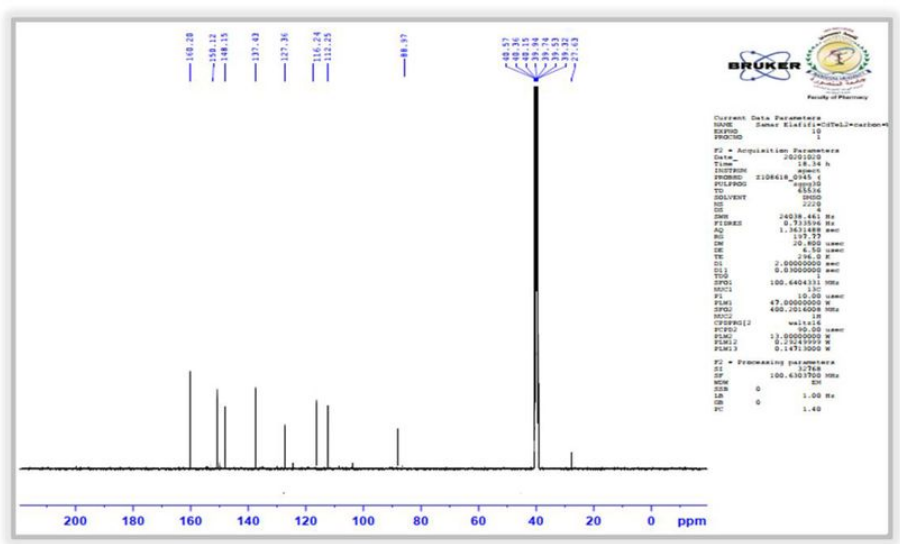

Figure 2

${ }^{13} \mathrm{C}$ NMR spectra of (A) HCPA and (B) $\mathrm{Na}_{2}\left[\mathrm{Cd}(\mathrm{CPA})\left(\mathrm{TeO}_{3}\right)\left(\mathrm{H}_{2} \mathrm{O}\right) \mathrm{Cl}\right] .2 \mathrm{H}_{2} \mathrm{O}$ complex 


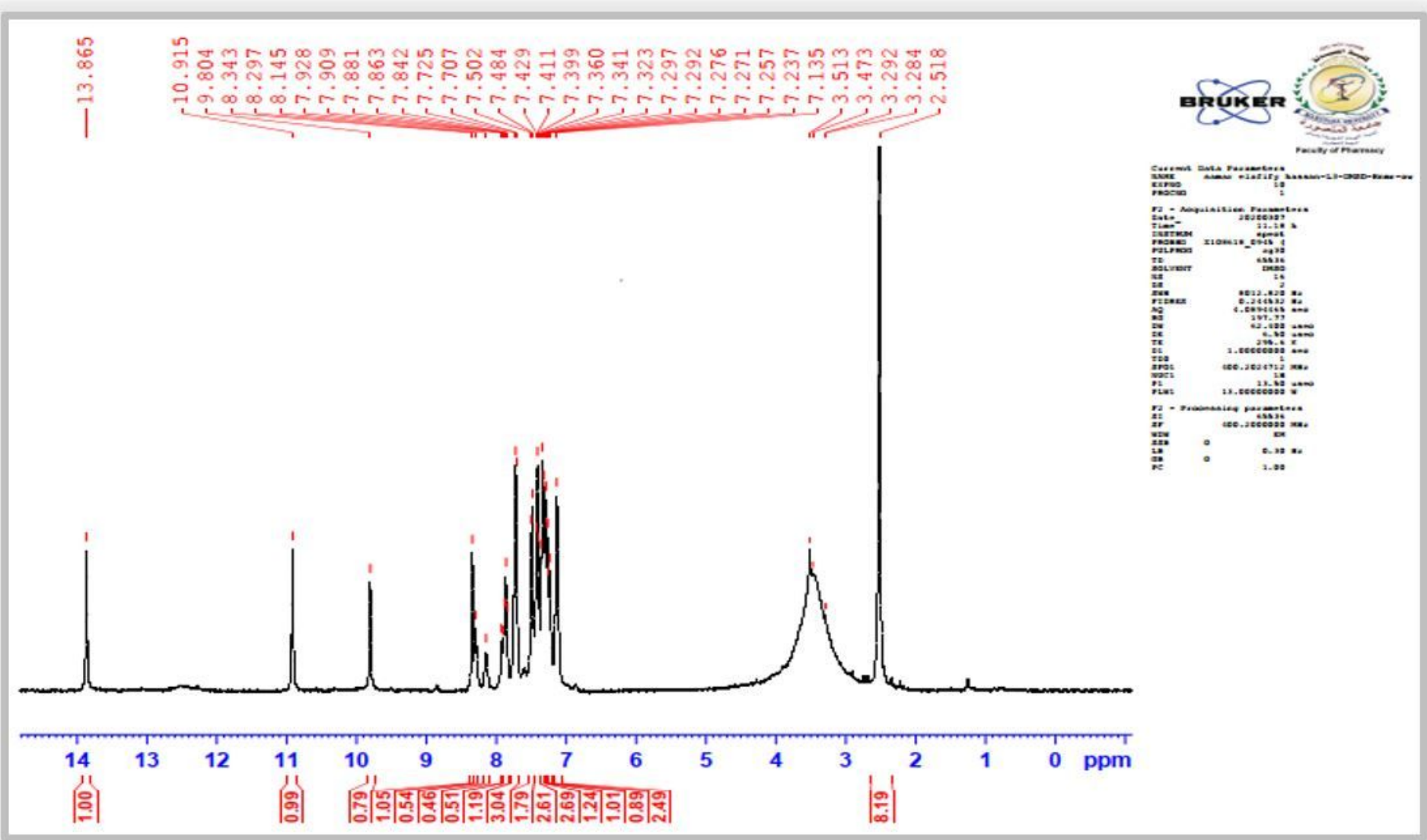

Figure 3

${ }^{1} \mathrm{H}$ NMR spectra of HCMPPA ligand 
(A)

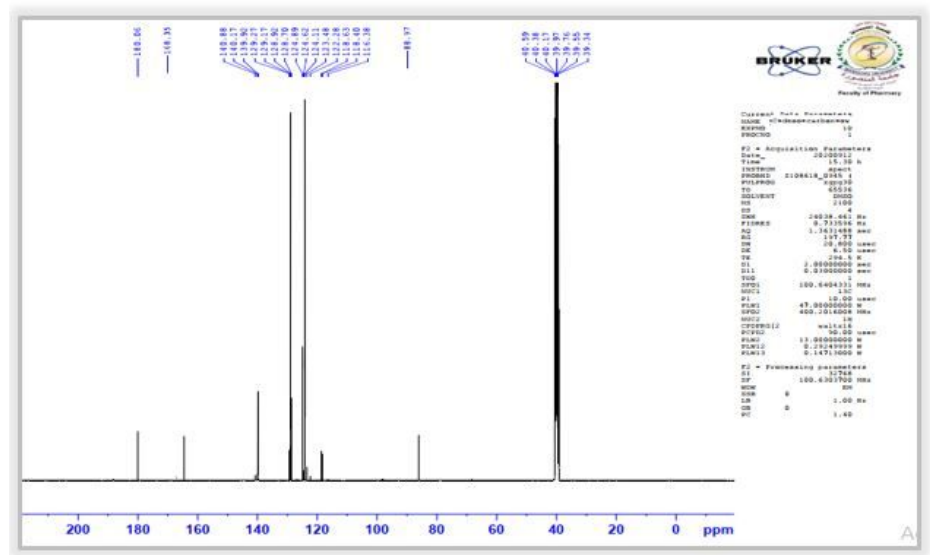

(B)

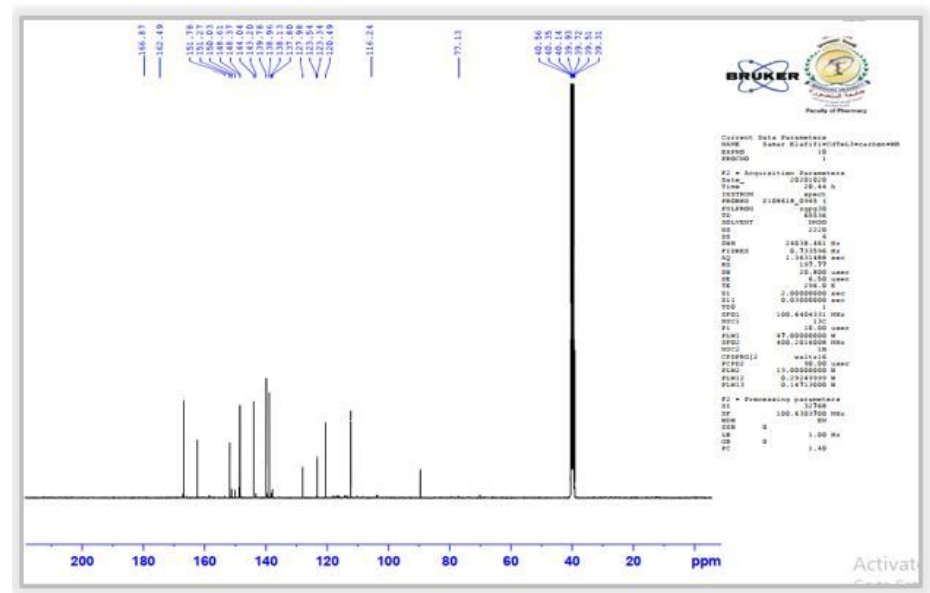

Figure 4

${ }^{13} \mathrm{C}$ NMR spectra of (A) HCMPPA and (B) $\mathrm{Na}_{2}\left[\mathrm{Cd}(\mathrm{CMPPA})\left(\mathrm{TeO}_{3}\right)\left(\mathrm{H}_{2} \mathrm{O}\right) \mathrm{Cl}\right] .2 \mathrm{H}_{2} \mathrm{O}$ complex 


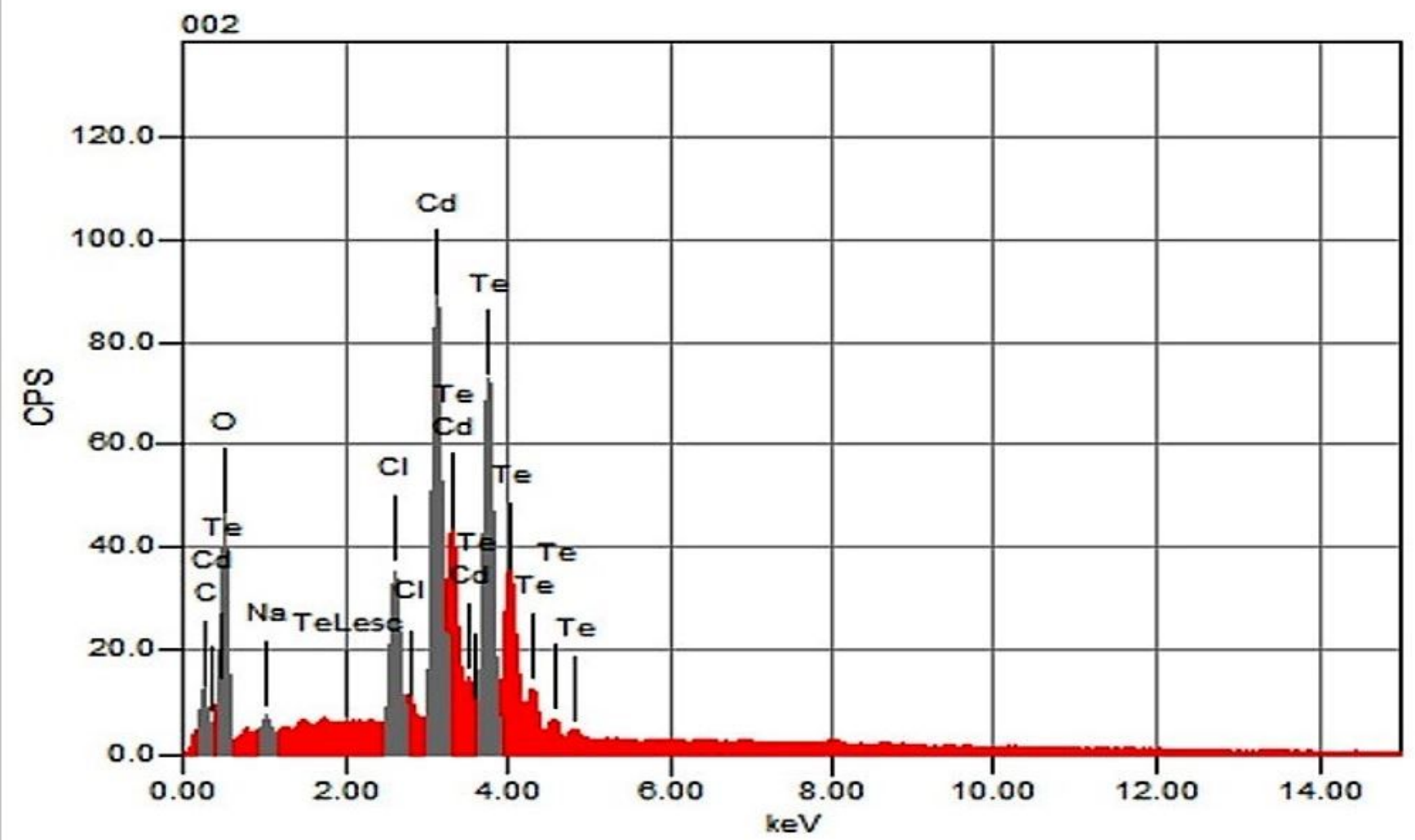

Figure 5

EDX analysis of $\mathrm{Na}_{2}\left[\mathrm{Cd}(\mathrm{CPA})\left(\mathrm{TeO}_{3}\right)\left(\mathrm{H}_{2} \mathrm{O}\right) \mathrm{Cl}\right] \cdot 2 \mathrm{H}_{2} \mathrm{O}$ complex

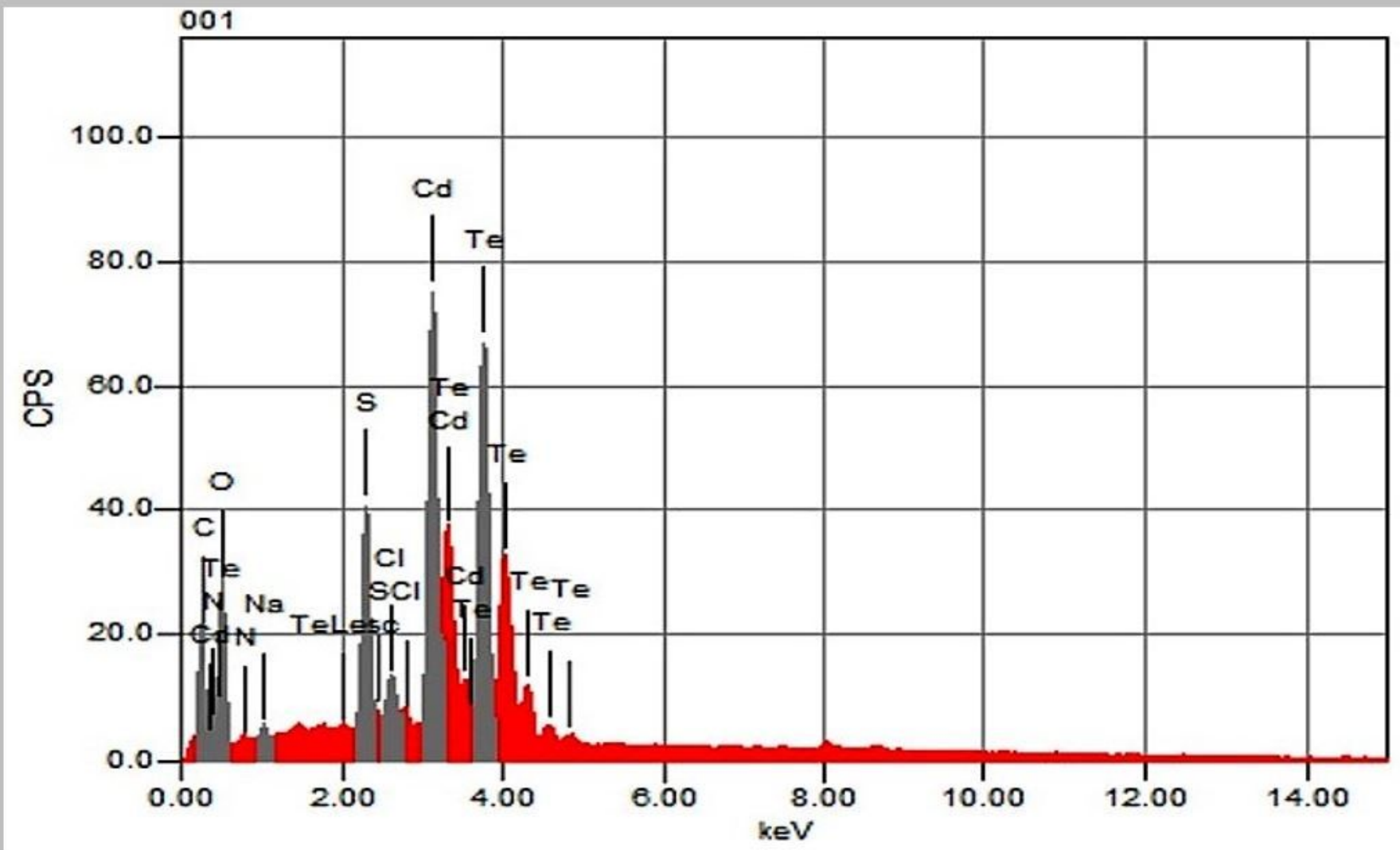


Figure 6

EDX analysis of $\mathrm{Na}_{2}\left[\mathrm{Cd}(\mathrm{CMPPA})\left(\mathrm{TeO}_{3}\right)\left(\mathrm{H}_{2} \mathrm{O}\right) \mathrm{Cl}\right] .2 \mathrm{H}_{2} \mathrm{O}$ complex

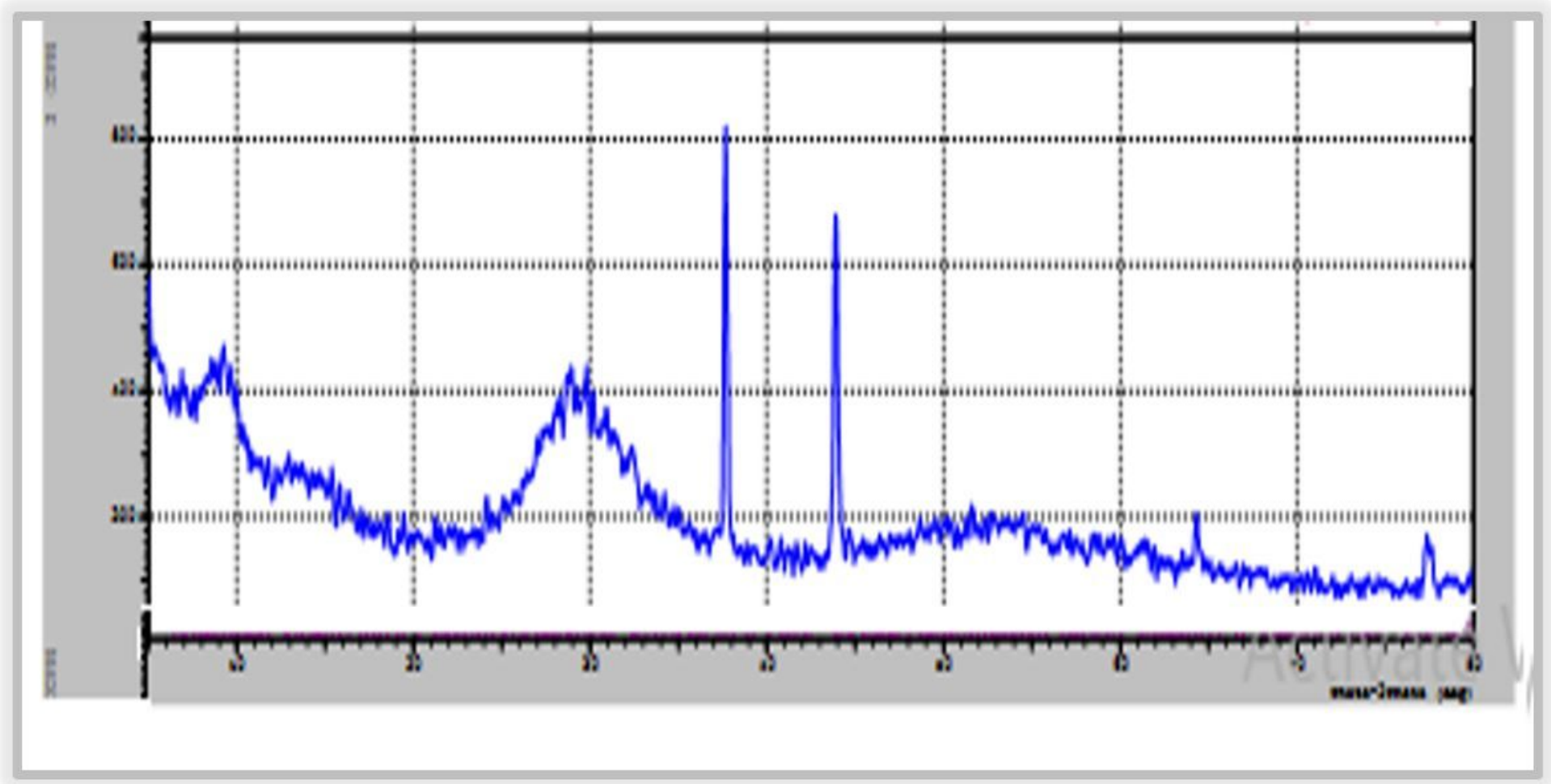

Figure 7

XRD of $\mathrm{Na}_{2}\left[\mathrm{Cd}(\mathrm{CPA})\left(\mathrm{TeO}_{3}\right)\left(\mathrm{H}_{2} \mathrm{O}\right) \mathrm{Cl}\right] \cdot 2 \mathrm{H}_{2} \mathrm{O}$ complex 


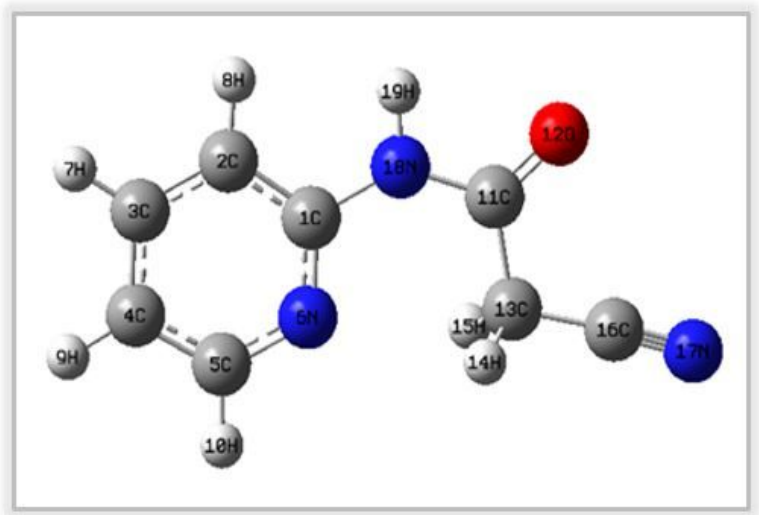

(B)

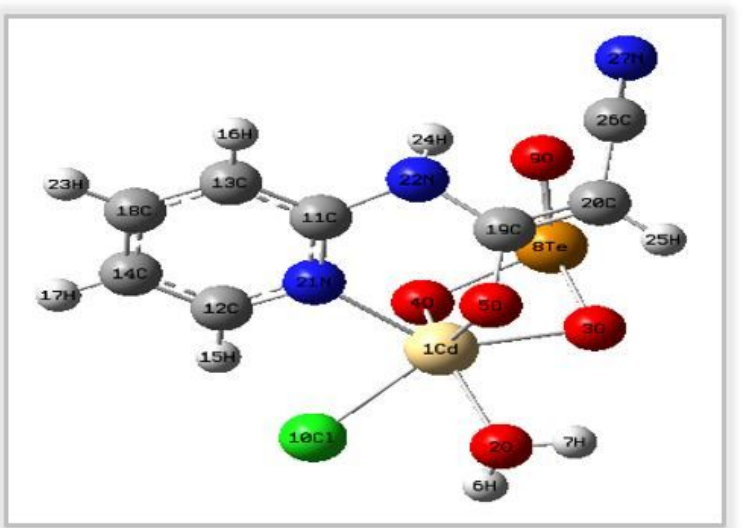

Figure 8

Molecular modeling of (A) HCPA and (B) $\mathrm{Na}_{2}\left[\mathrm{Cd}(\mathrm{CPA})\left(\mathrm{TeO}_{3}\right)\left(\mathrm{H}_{2} \mathrm{O}\right) \mathrm{Cl}\right] \cdot 2 \mathrm{H}_{2} \mathrm{O}$ complex 
(A)

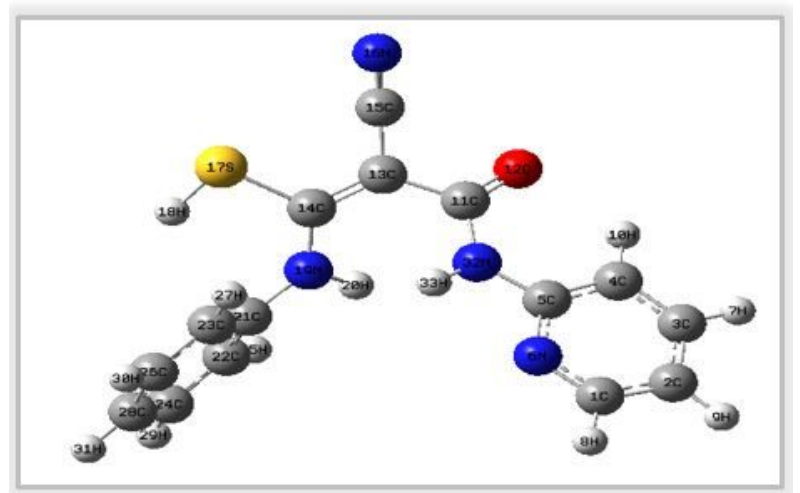

(B)

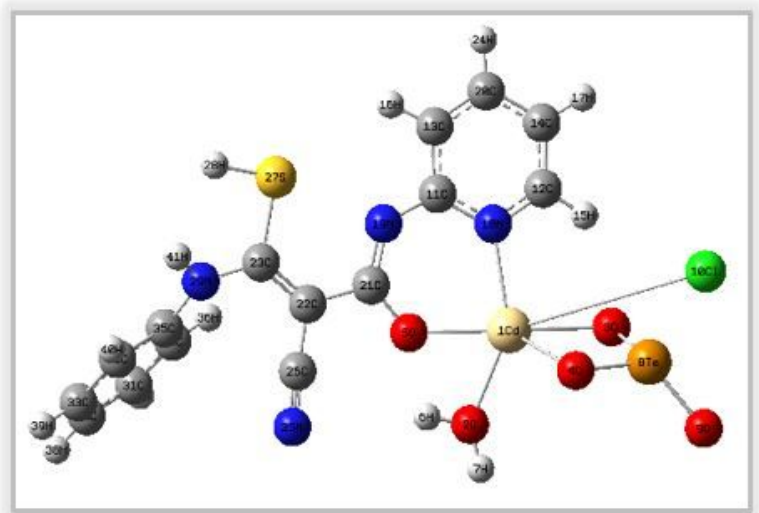

Figure 9

Molecular modeling of (A) HCMPPA and (B) $\mathrm{Na}_{2}\left[\mathrm{Cd}(\mathrm{CMPPA})\left(\mathrm{TeO}_{3}\right)\left(\mathrm{H}_{2} \mathrm{O}\right) \mathrm{Cl}\right] .2 \mathrm{H}_{2} \mathrm{O}$ complex 


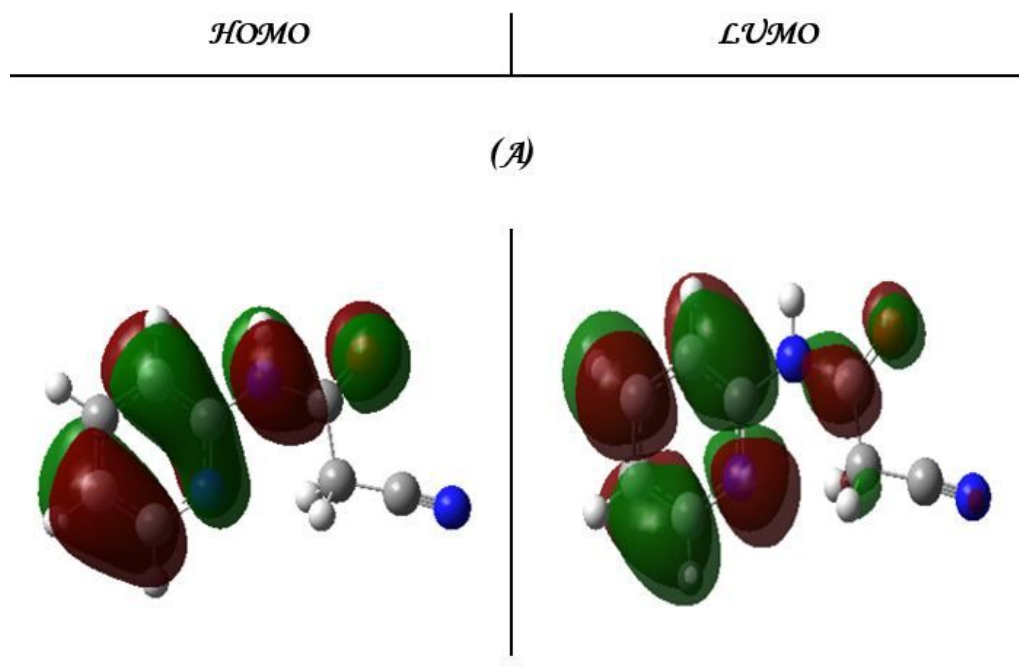

\section{(B)}

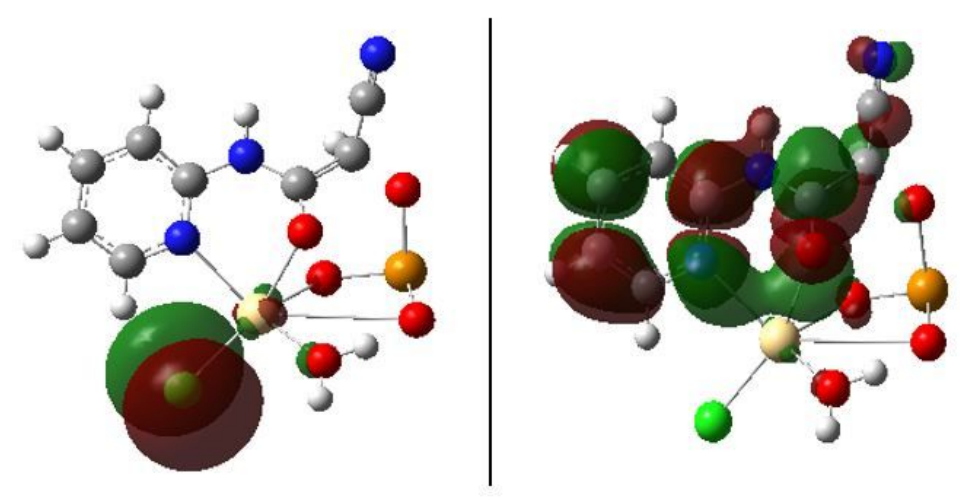

Figure 10

The frontier molecular orbitals (FMOs) of (A) HCPA and (B) $\mathrm{Na}_{2}\left[\mathrm{Cd}(\mathrm{CPA})\left(\mathrm{TeO}_{3}\right)\left(\mathrm{H}_{2} \mathrm{O}\right) \mathrm{Cl}\right] .2 \mathrm{H}_{2} \mathrm{O}$ complex 

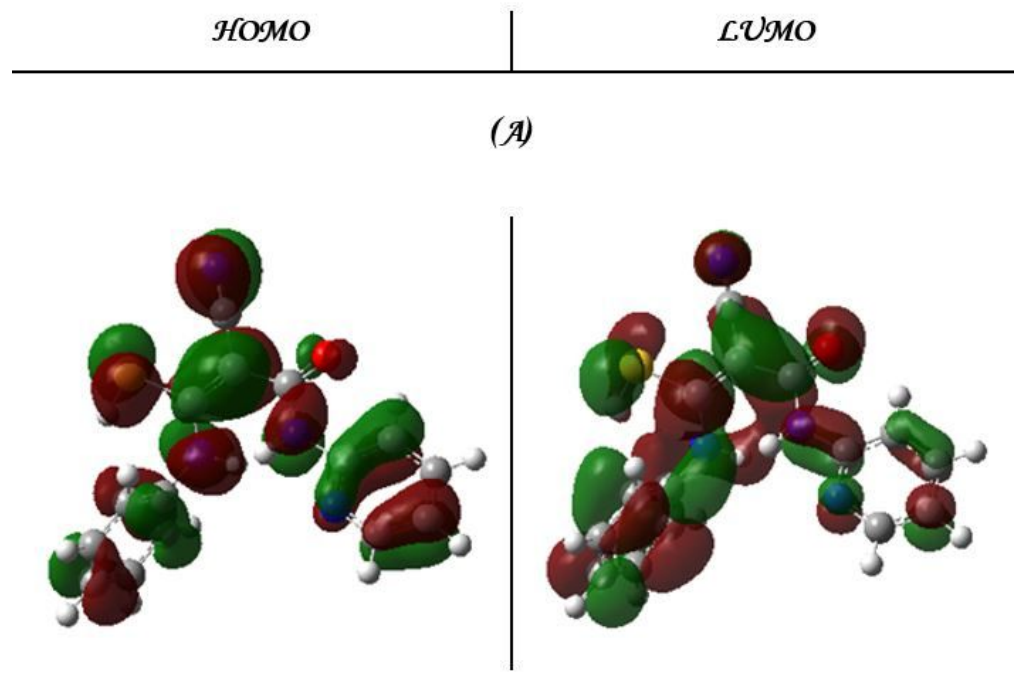

(B)

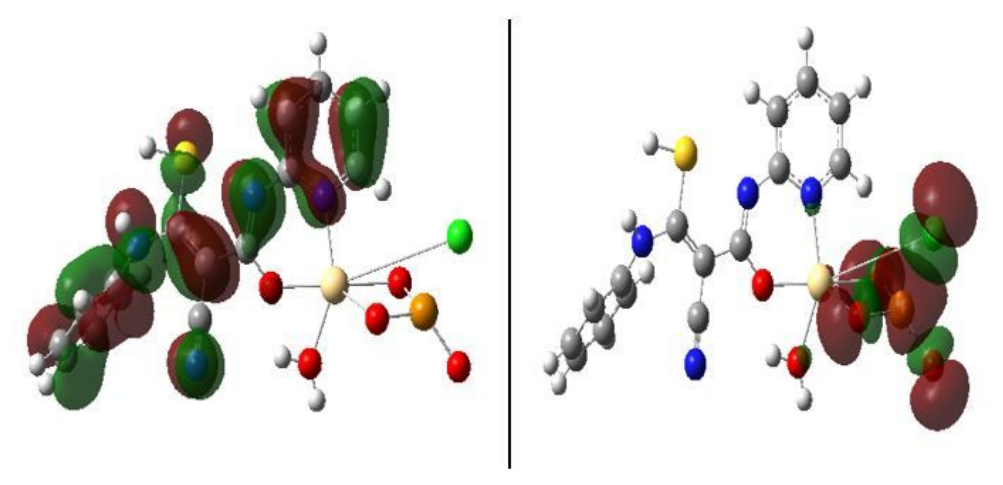

Figure 11

The frontier molecular orbitals (FMOs) of (A) HCMPPA and (B) $\mathrm{Na}_{2}\left[\mathrm{Cd}(\mathrm{CMPPA})\left(\mathrm{TeO}_{3}\right)\left(\mathrm{H}_{2} \mathrm{O}\right) \mathrm{Cl}\right] 2 \mathrm{H}_{2} \mathrm{O}$ complex 
(A)

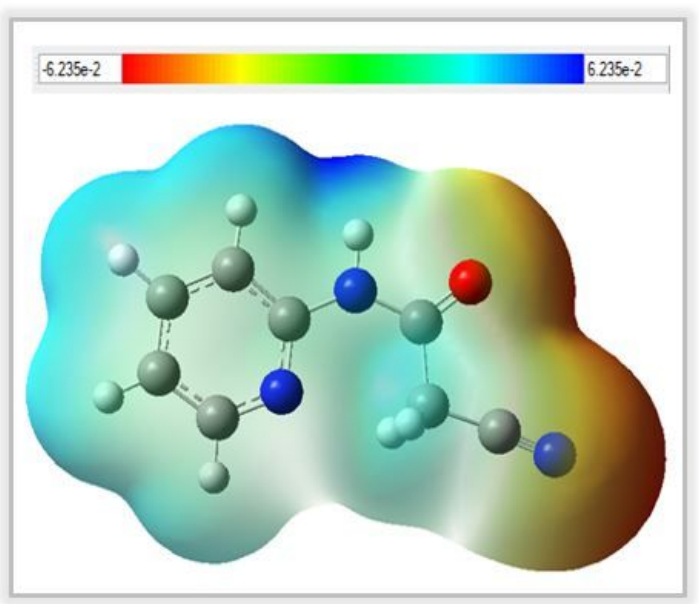

(B)

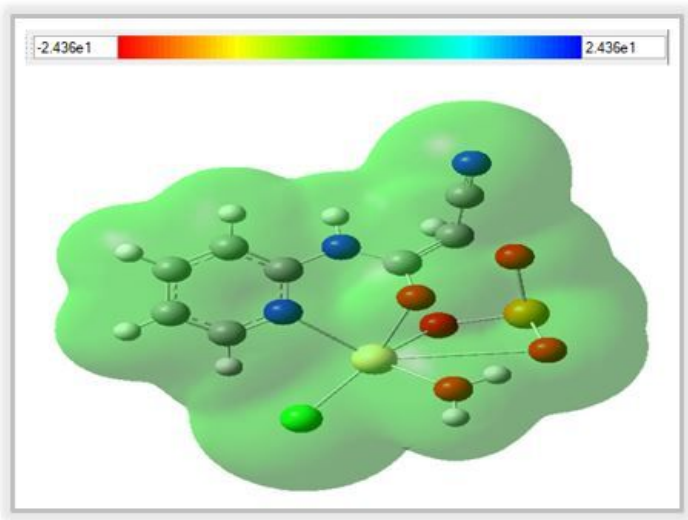

Figure 12

Molecular electrostatic potential map of (A) HCPA and (B) $\mathrm{Na}_{2}\left[\mathrm{Cd}(\mathrm{CPA})\left(\mathrm{TeO}_{3}\right)\left(\mathrm{H}_{2} \mathrm{O}\right) \mathrm{Cl}\right] .2 \mathrm{H}_{2} \mathrm{O}$ complex 
(A)

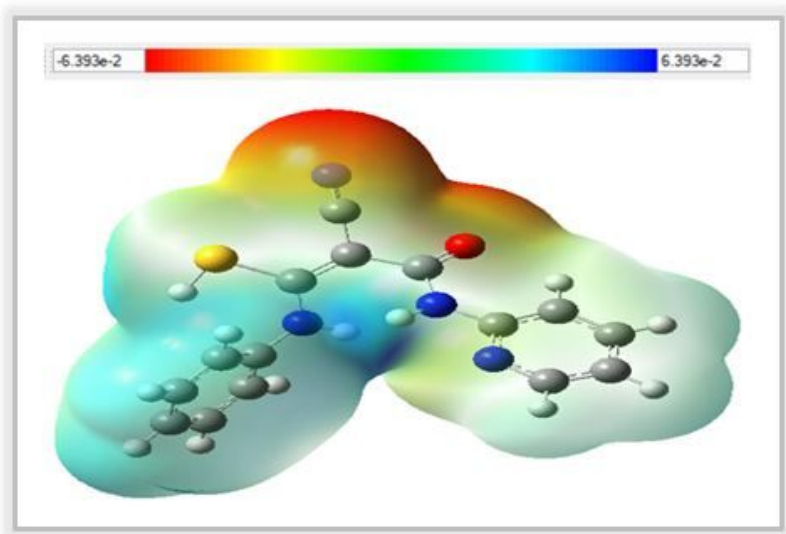

(B)

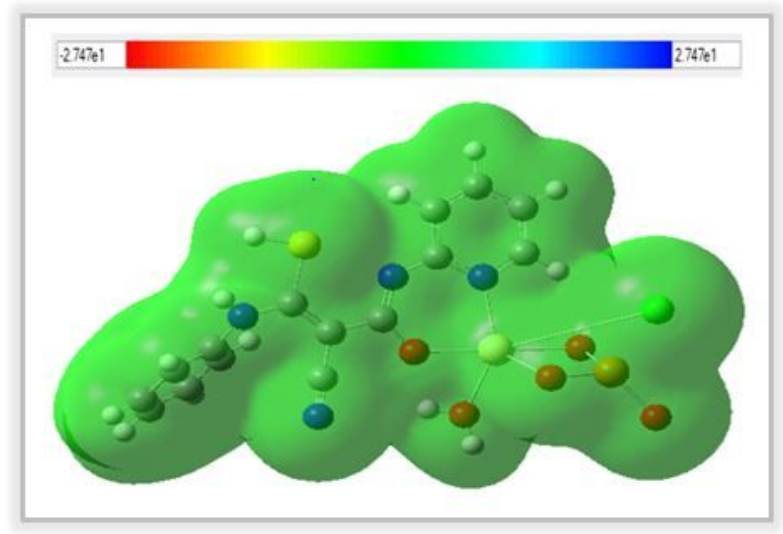

\section{Figure 13}

Molecular electrostatic potential map of (A) HCMPPA and (B) $\mathrm{Na}_{2}\left[\mathrm{Cd}(\mathrm{CMPPA})\left(\mathrm{TeO}_{3}\right)\left(\mathrm{H}_{2} \mathrm{O}\right) \mathrm{Cl}\right] \cdot 2 \mathrm{H}_{2} \mathrm{O}$ complex 


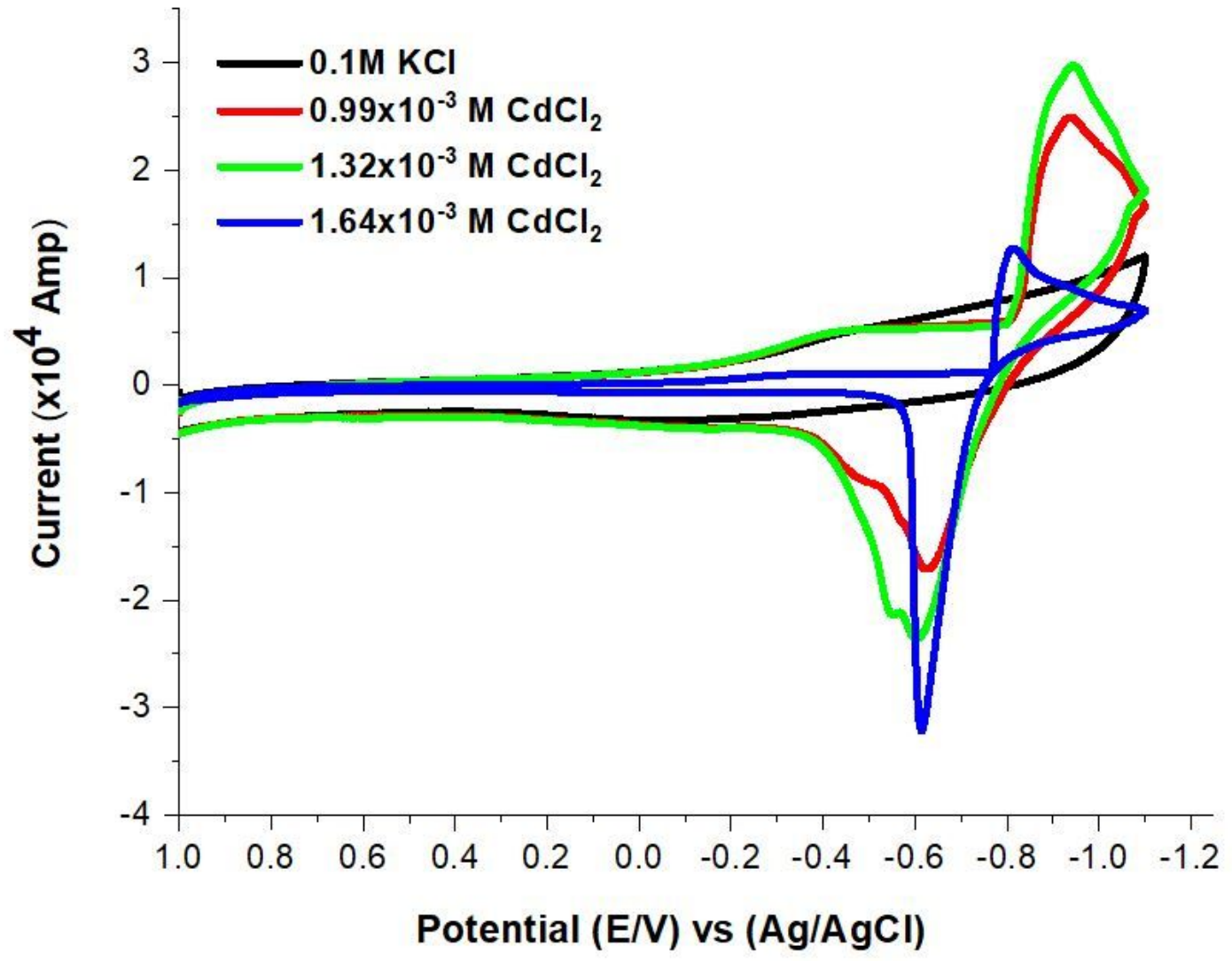

Figure 14

Cyclic voltammograms of $\mathrm{CdCl}_{2}$ in $0.1 \mathrm{M} \mathrm{KCl}$ at scan rate $0.1 \mathrm{~V} / \mathrm{s}$ and at $301.15 \mathrm{~K}$ 


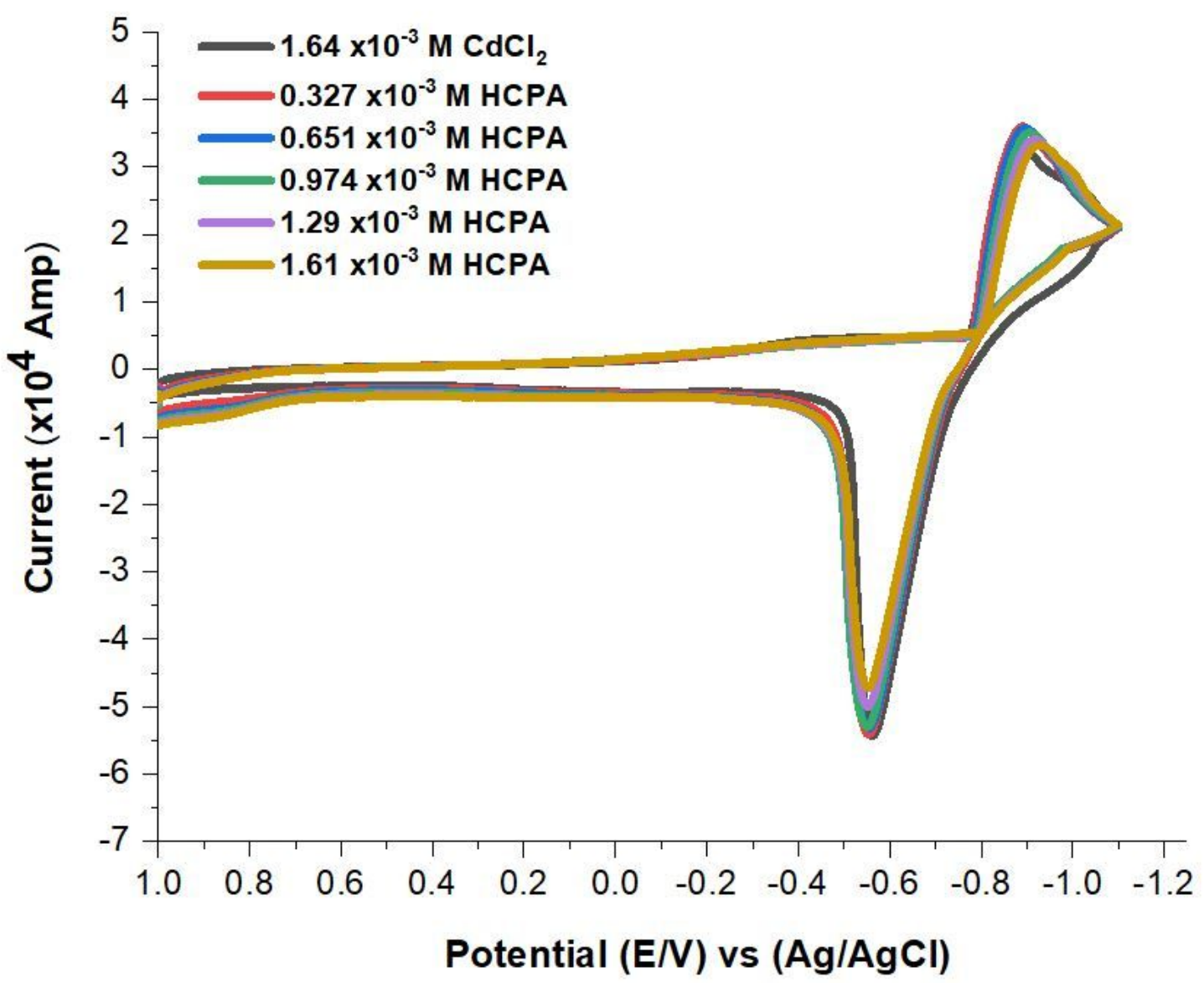

Figure 15

Cyclic voltammograms of $1.64 \times 10^{-3} \mathrm{M} \mathrm{CdCl}_{2}$ in $0.1 \mathrm{M} \mathrm{KCl}$ in presence of different concentrations of $\mathrm{HCPA}$ at scan rate $0.1 \mathrm{~V} / \mathrm{s}$ and at $301.15 \mathrm{~K}$ 
(a)

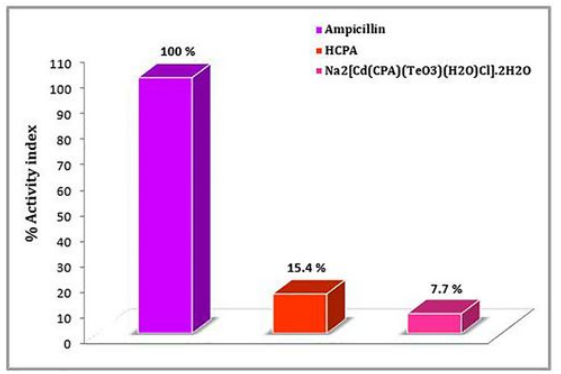

(B)

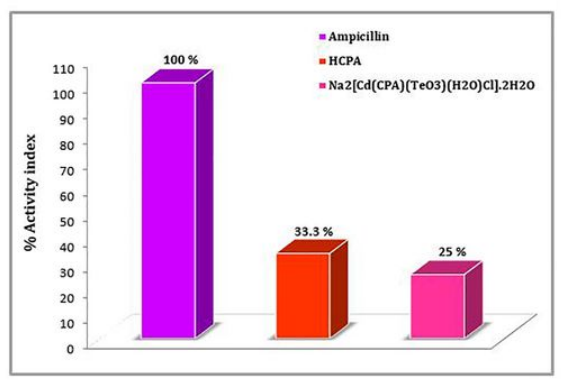

(c)

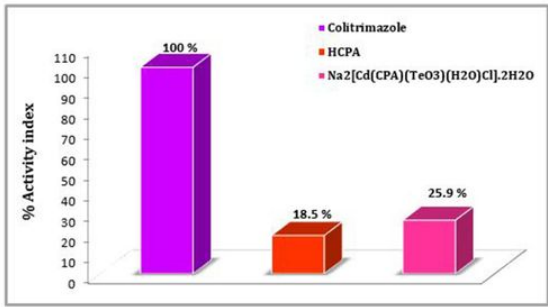

Figure 16

Effect of HCPA and its Cd(II) complex toward (A) E. Coli, (B) S. aureus and

(C) C.Albicans 


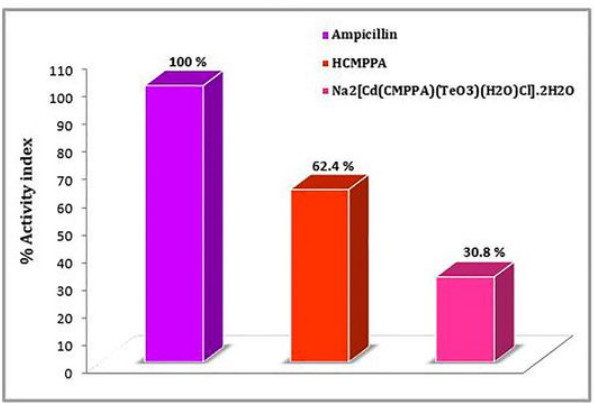

(B)

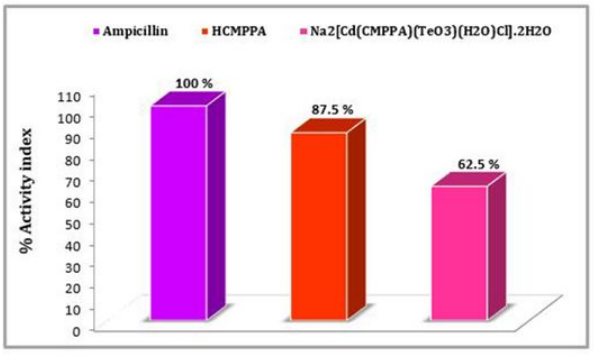

(c)

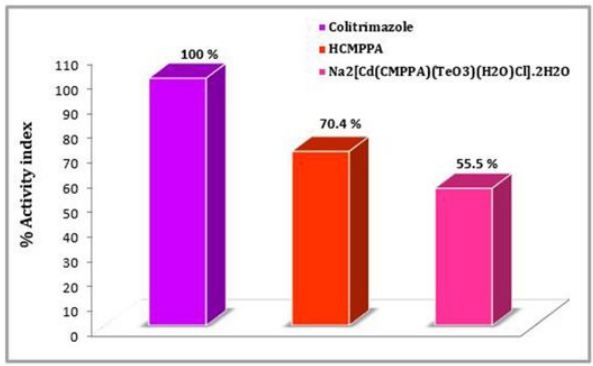

Figure 17

Effect of HCMPPA and its Cd(II) complex toward (A) E. Coli; (B) S. aureusand

(C) C.Albicans 


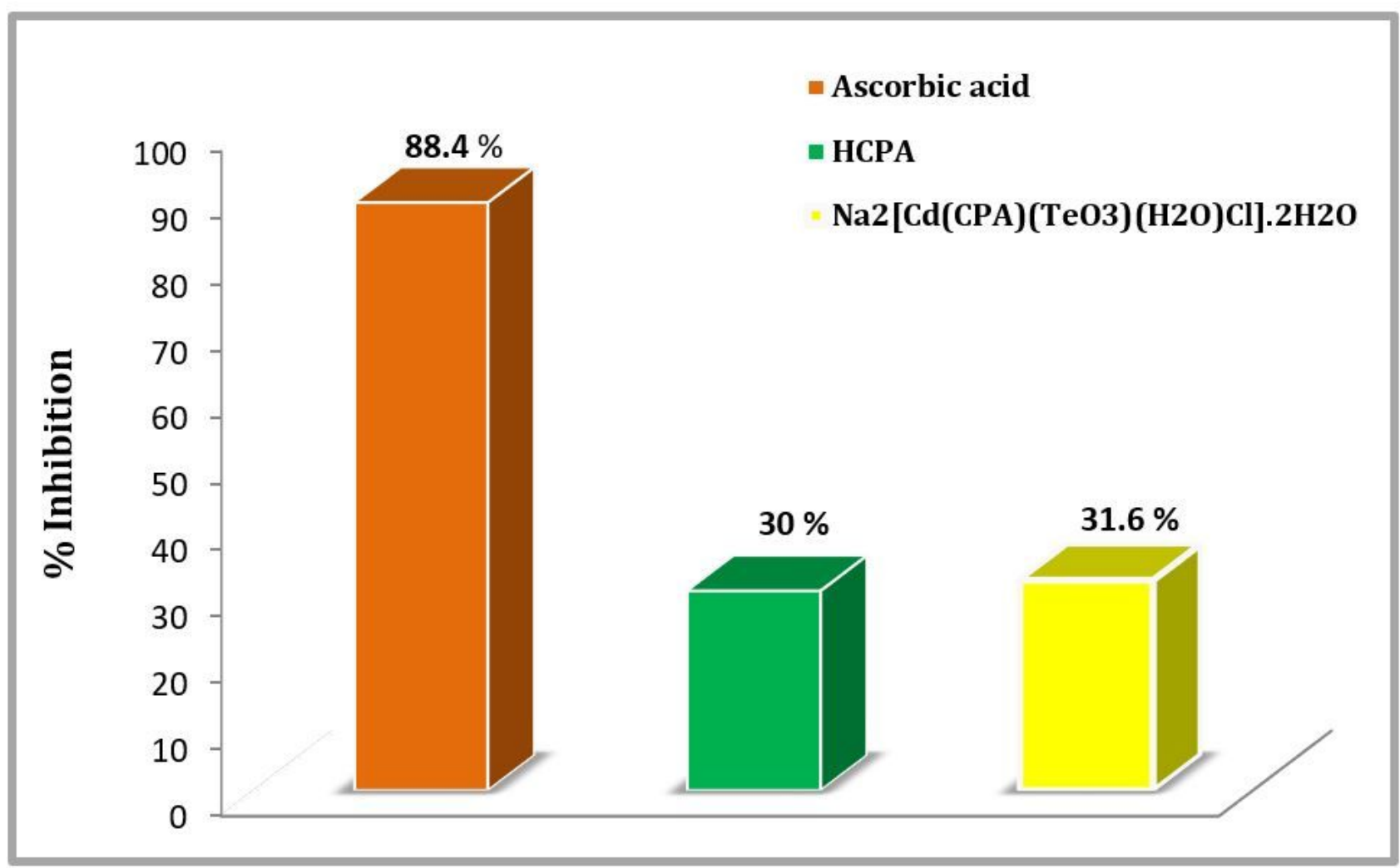

Figure 18

The antioxidant activity assay ABTS method for HCPA and its Cd(II) complex 


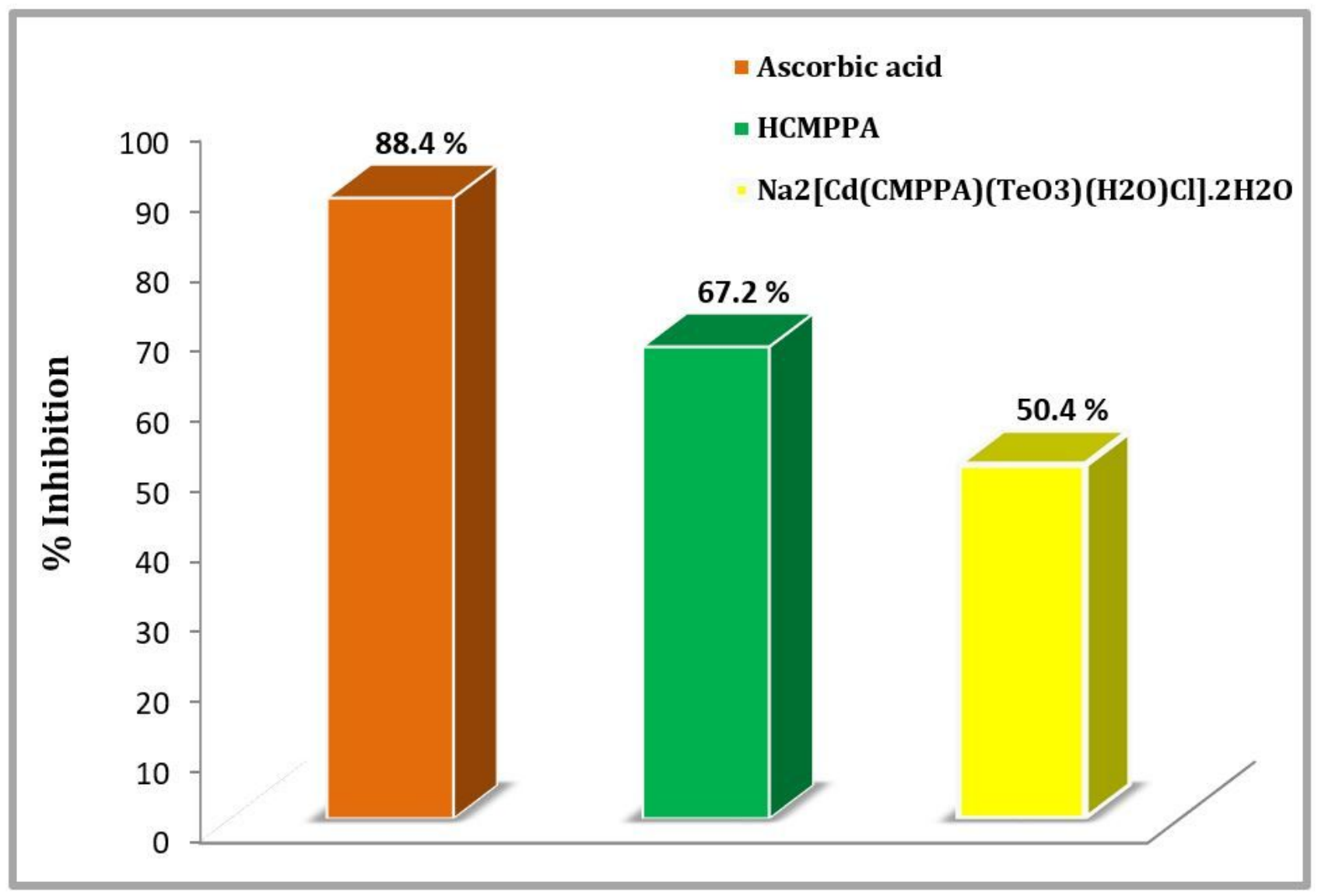

Figure 19

The antioxidant activity assay ABTS method for HCMPPA and its Cd(II) complex 


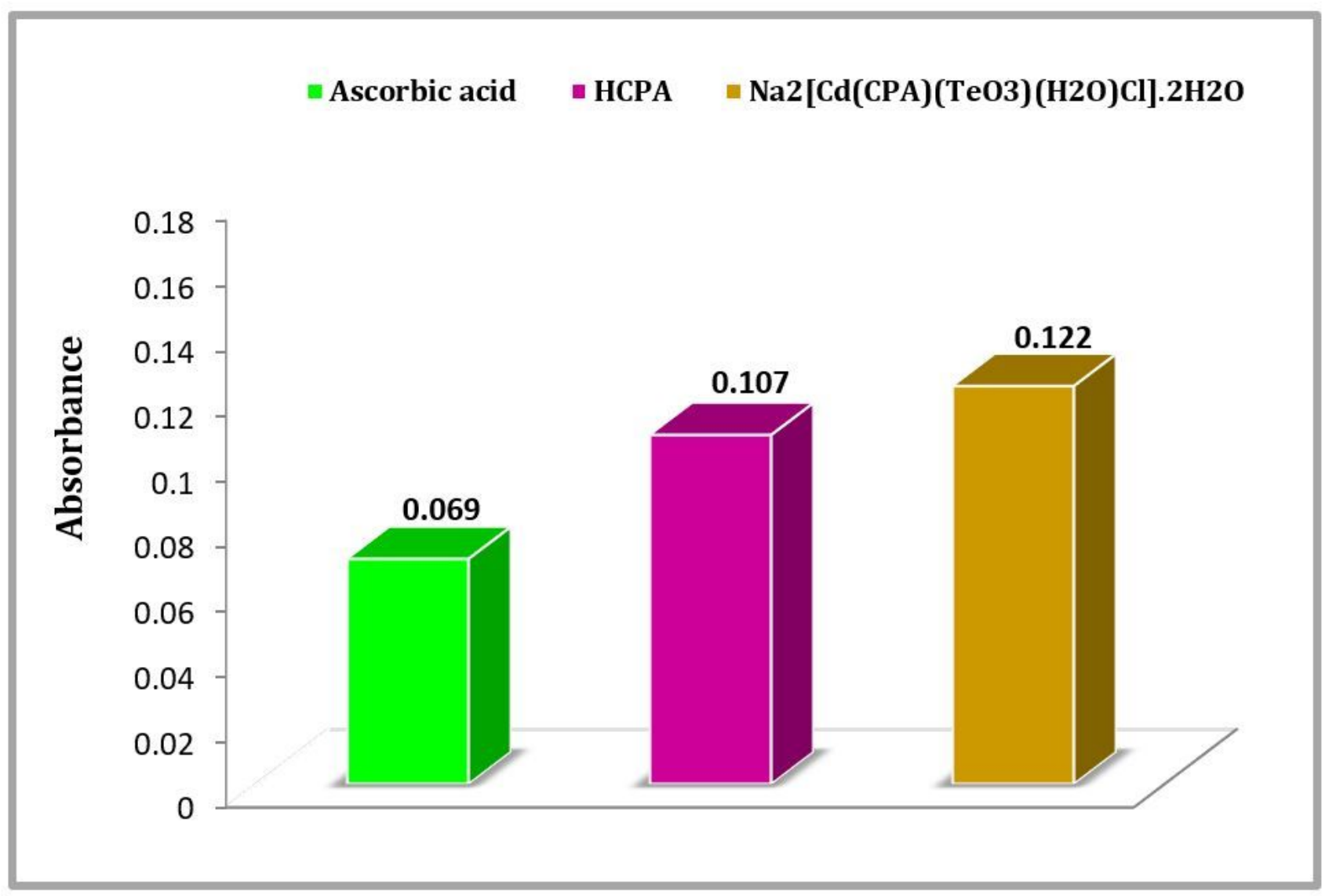

Figure 20

Bleomycin-dependent DNA damage assay of HCPA and its $\mathrm{Cd}(\mathrm{II})$ complex 


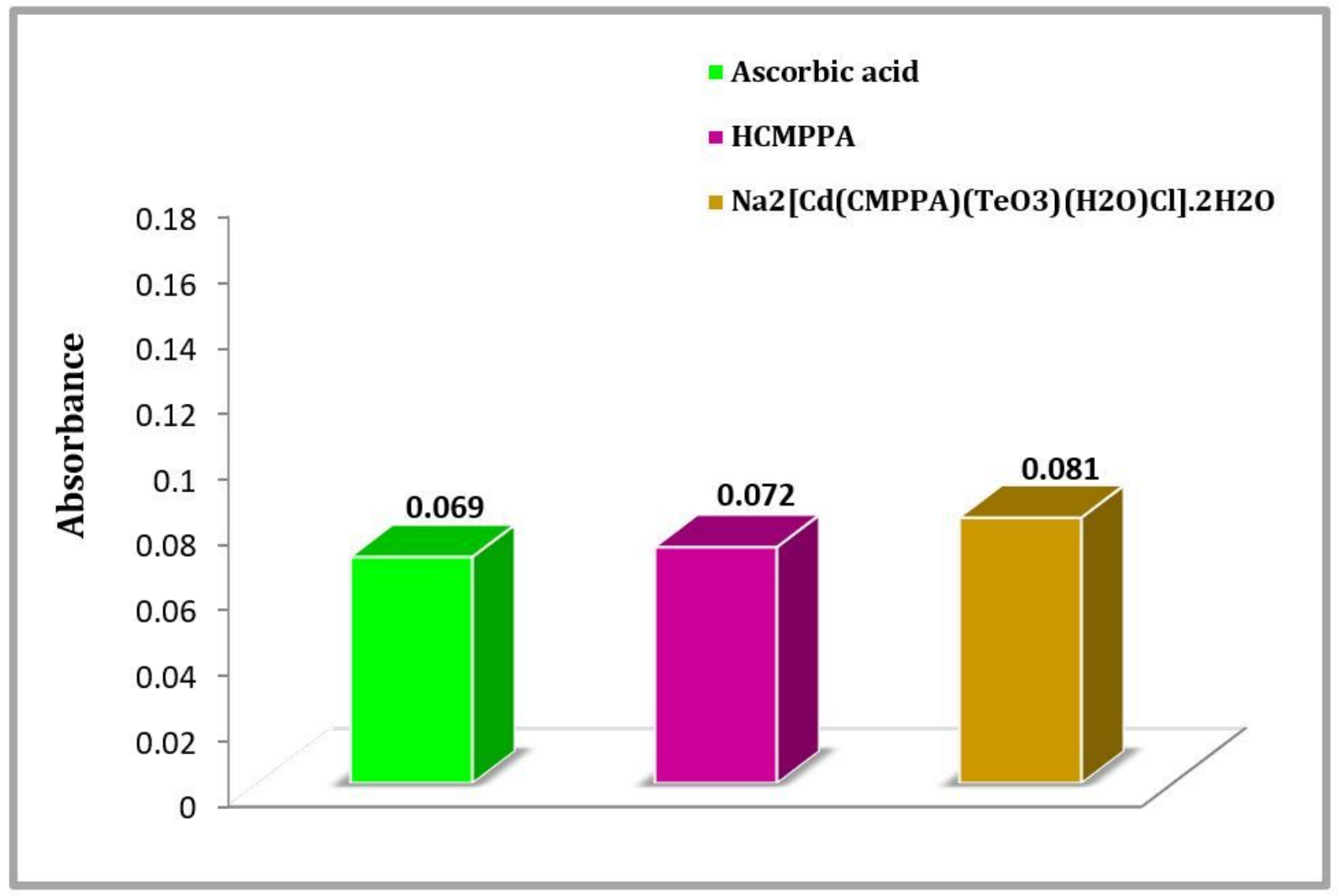

Figure 21

Bleomycin-dependent DNA damage assay of HCMPPA and its Cd(II) complex 
( A)

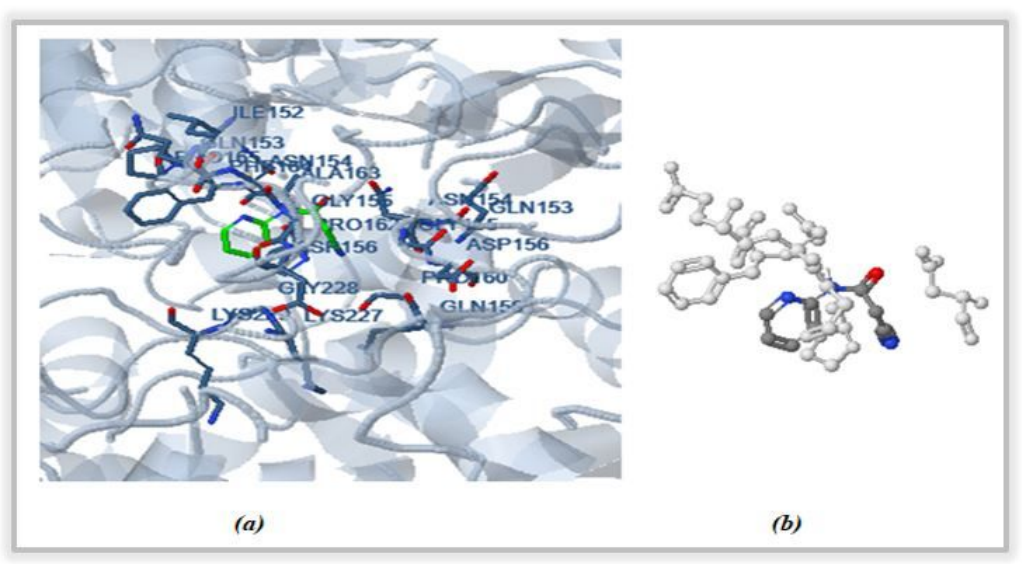

(B)

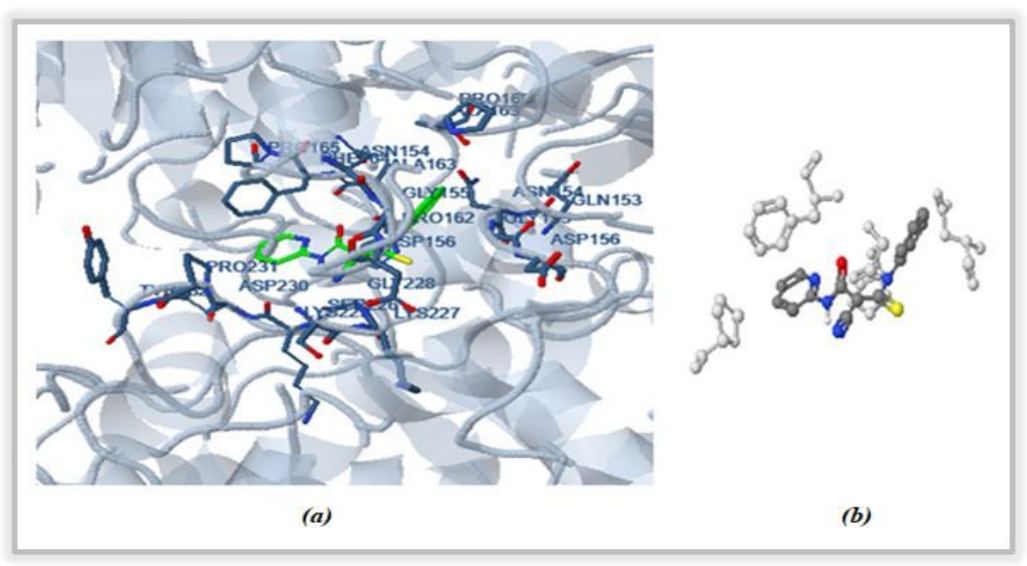

\section{Figure 22}

Ligands (A) HCPA and (B) HCMPPA (green in (a) and gray in (b)) in interaction with receptor of Escherichia coli (PDB code: 1xk6). 
(A)

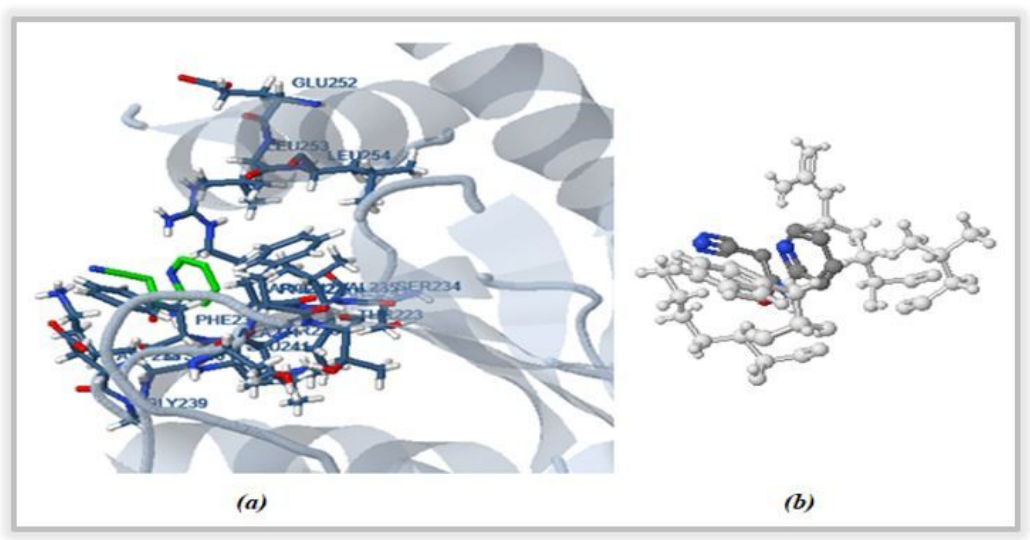

(B)

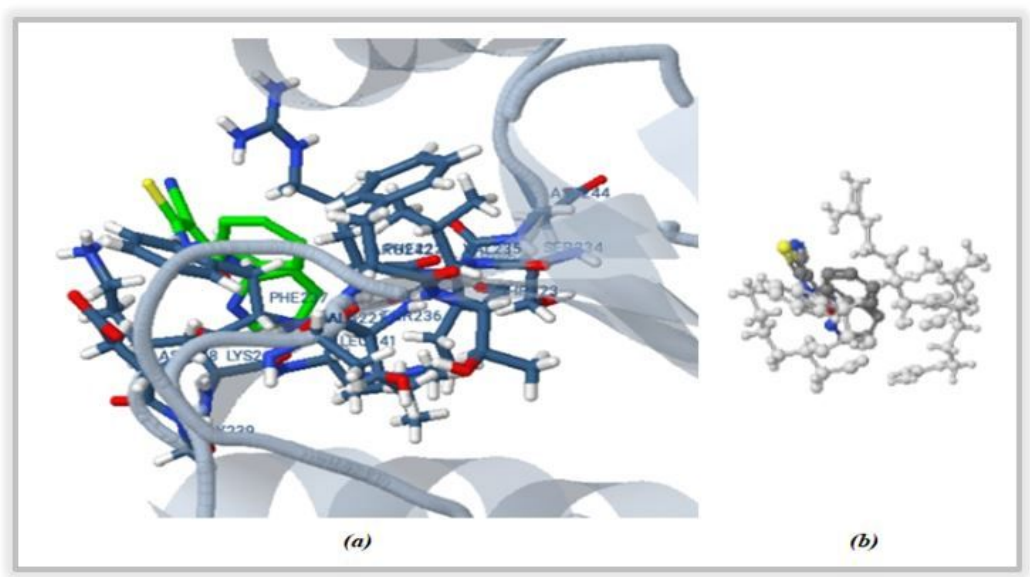

Figure 23

Ligands (A) HCPA and (B) HCMPPA (green in (a) and gray in (b)) in interaction with receptor of Staphylococcus aureus (PDB code: 6gyw). 


\section{(A)}

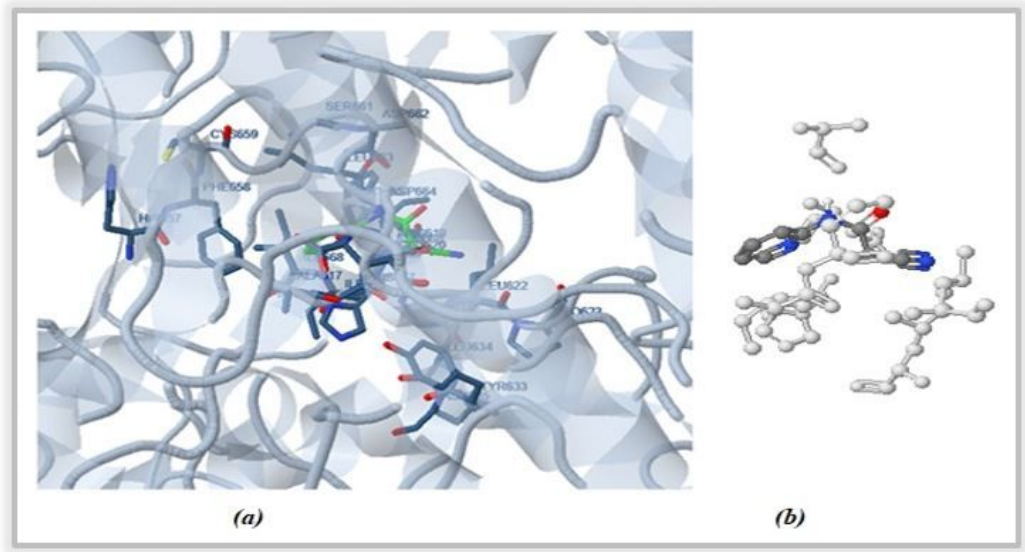

(B)

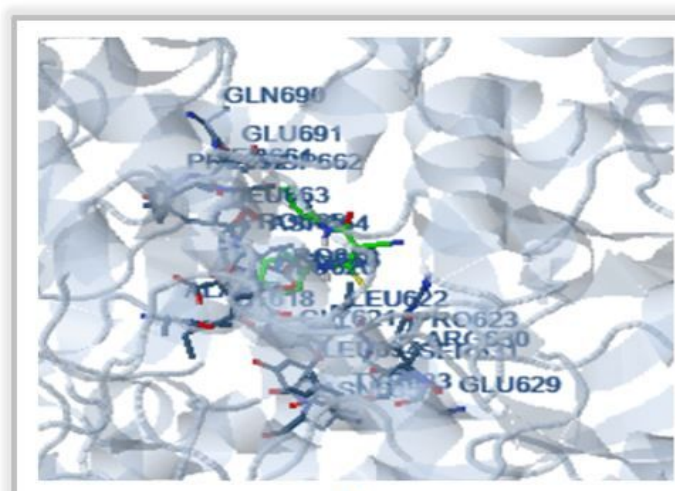

(a)

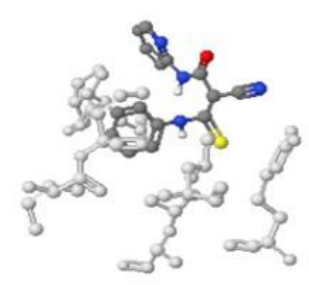

(b)

\section{Figure 24}

Ligands (A) HCPA and (B) HCMPPA (green in (a) and gray in (b)) in interaction with receptor of Candida albicans (PDB code: 3ppc). 
(A)

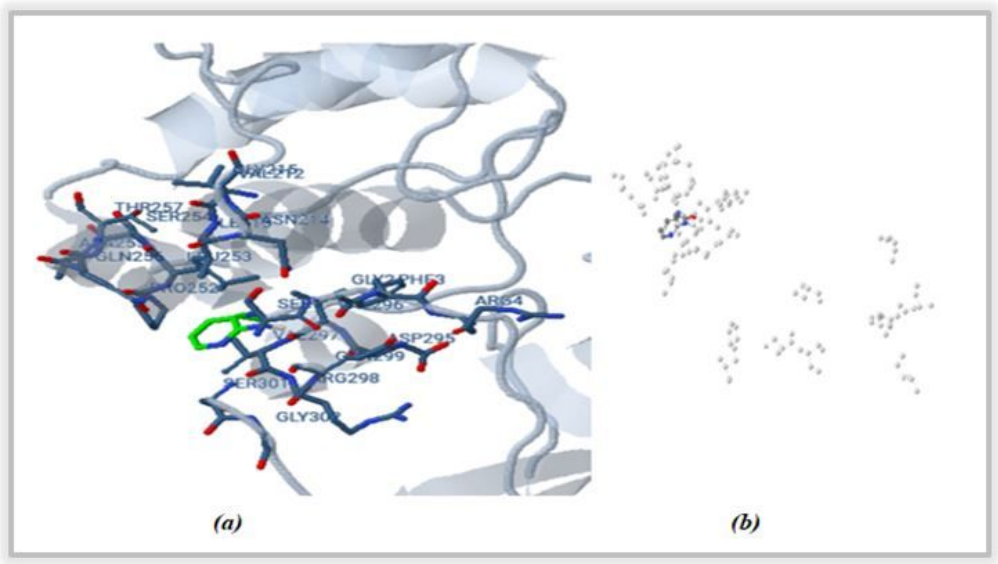

(B)

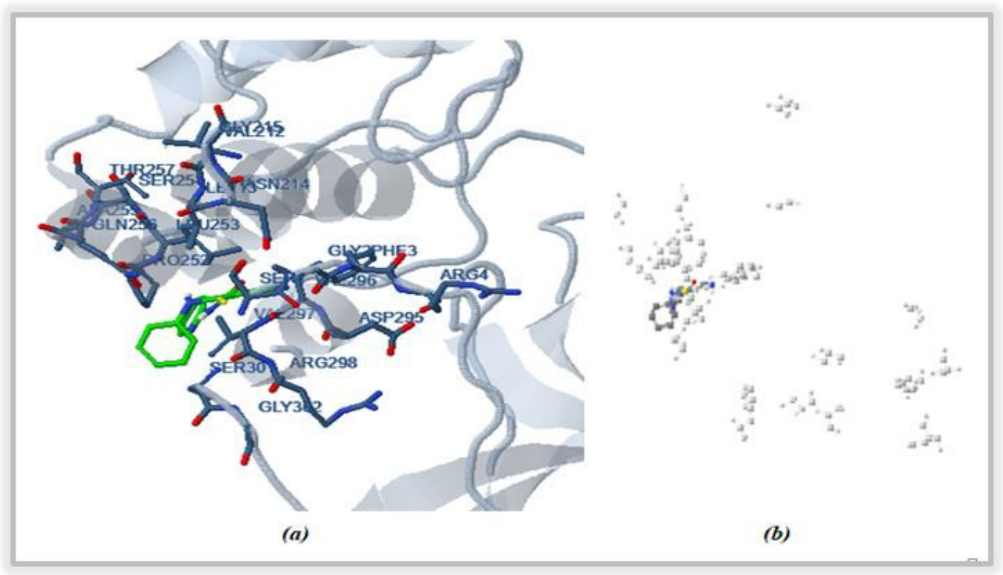

\section{Figure 25}

Ligands (A) HCPA and (B) HCMPPA (green in (a) and gray in (b)) in interaction with receptor of Covid 19(PDB code: 7jpy). 


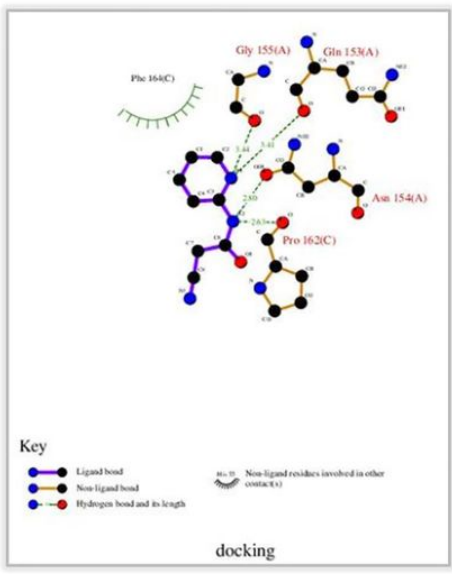

(B)

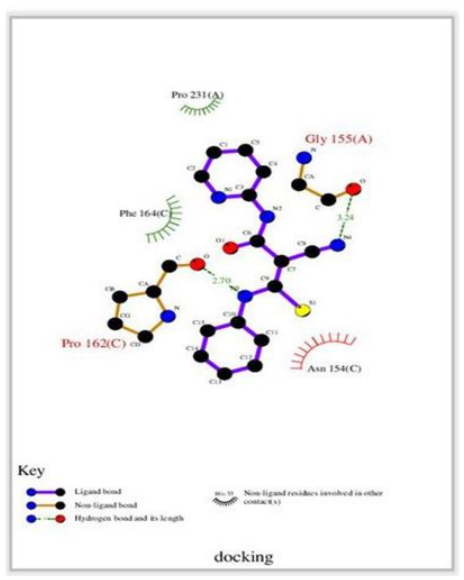

Figure 26

2D plot of interaction between ligands (A) HCPA and (B) HCMPPA and receptor of Escherichia coli (PDB code: 1xk6). 


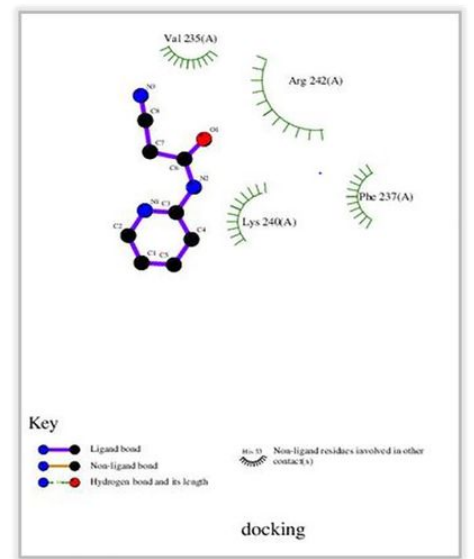

(B)

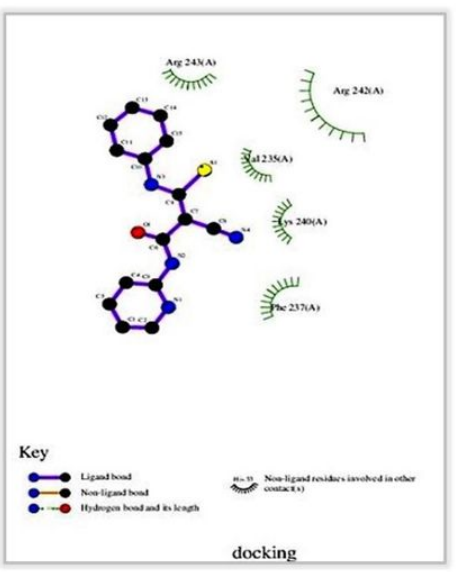

Figure 27

2D plot of interaction between ligands (A) HCPA and (B) HCMPPA and receptor of Staphylococcus aureus (PDB code: 6gyw). 


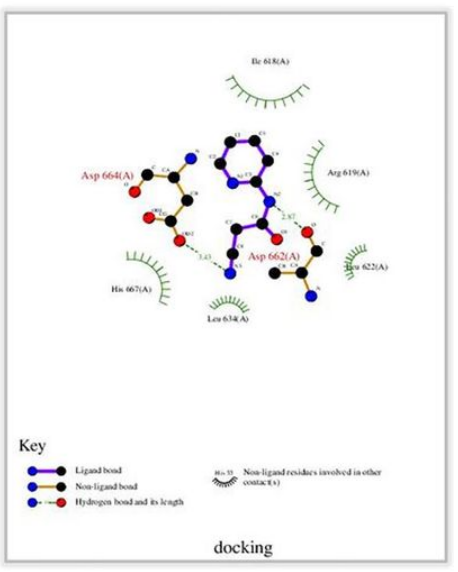

(B)

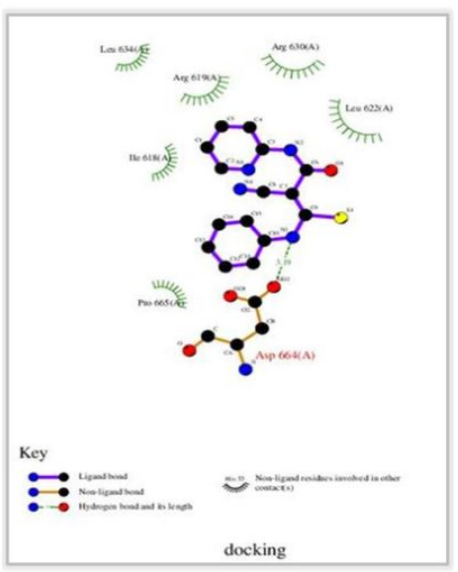

Figure 28

2D plot of interaction between ligands (A) HCPA and (B) HCMPPA and receptor of Candida albicans(PDB code: 3ppc). 


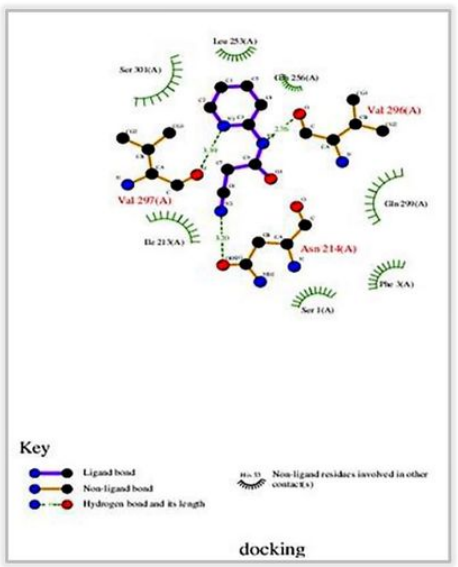

(B)

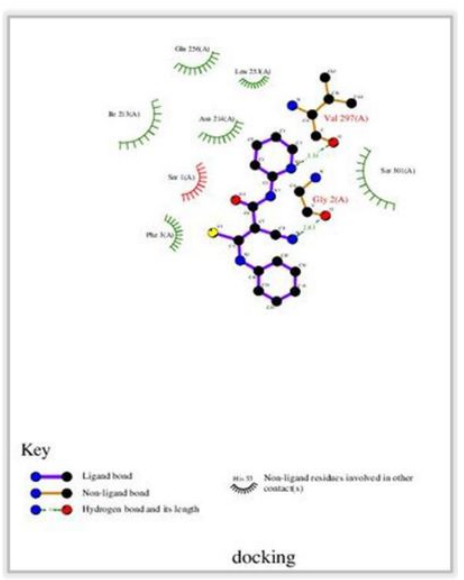

Figure 29

2D plot of interaction between ligands (A) HCPA and (B) HCMPPA and receptor of Covid 19(PDB code: 7jpy). 
(A)

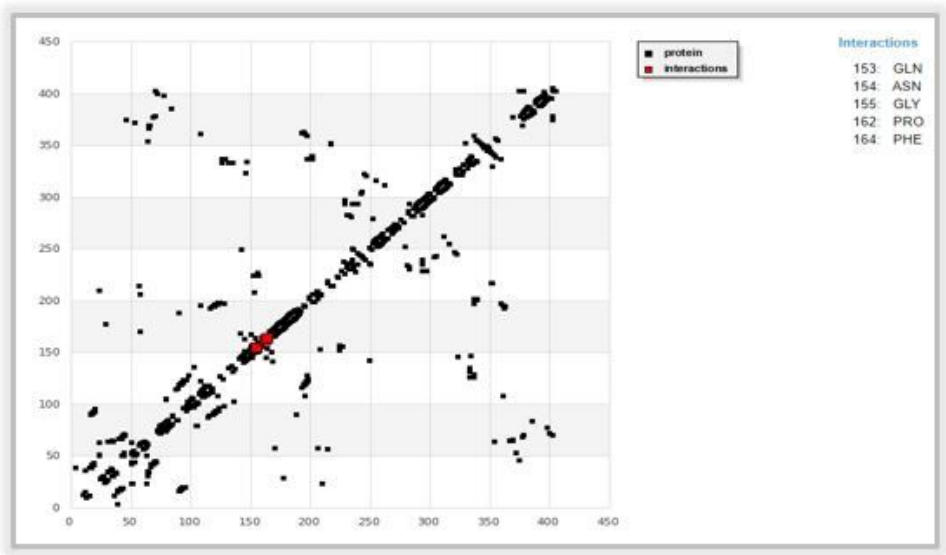

(B)

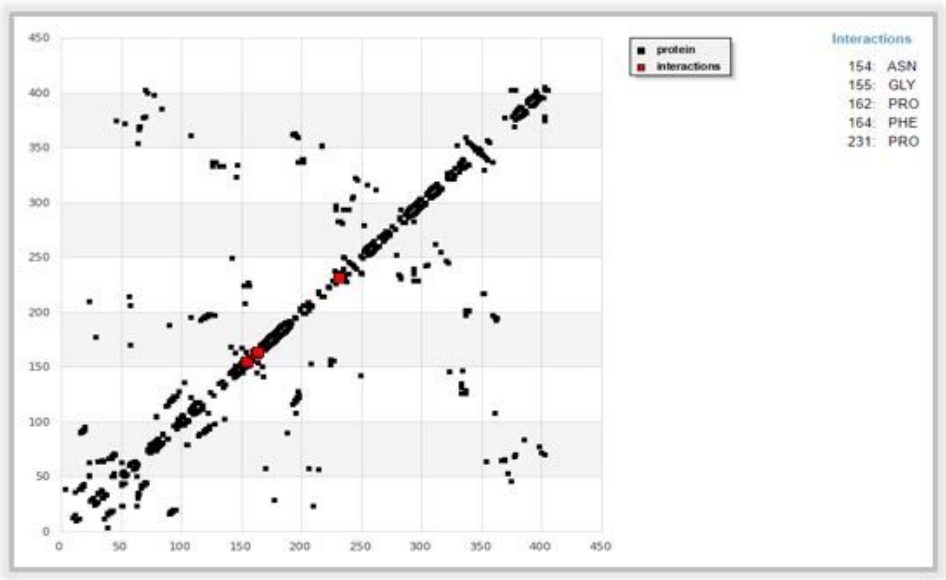

Figure 30

HB plot of interaction between ligands (A) HCPA and (B) HCMPPA and receptor of Escherichia coli (PDB code: 1xk6) 
(A)

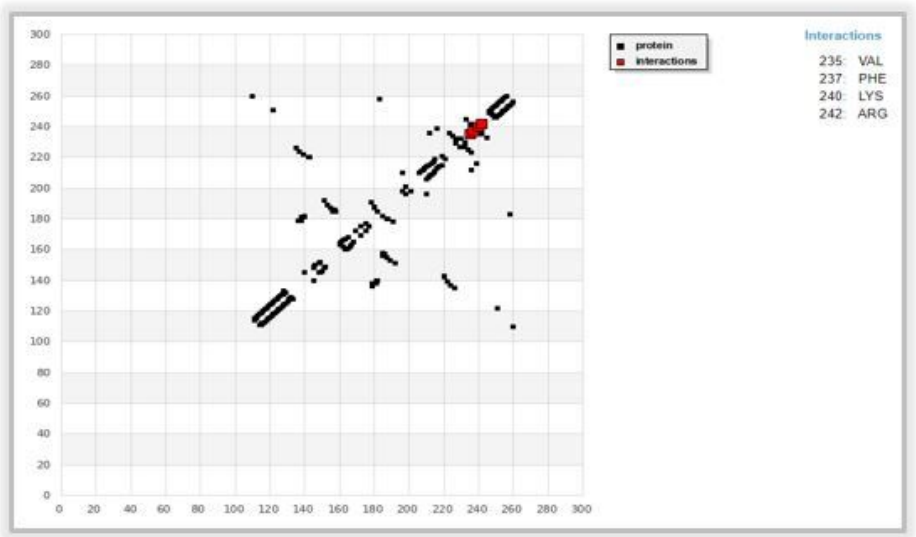

(卉)

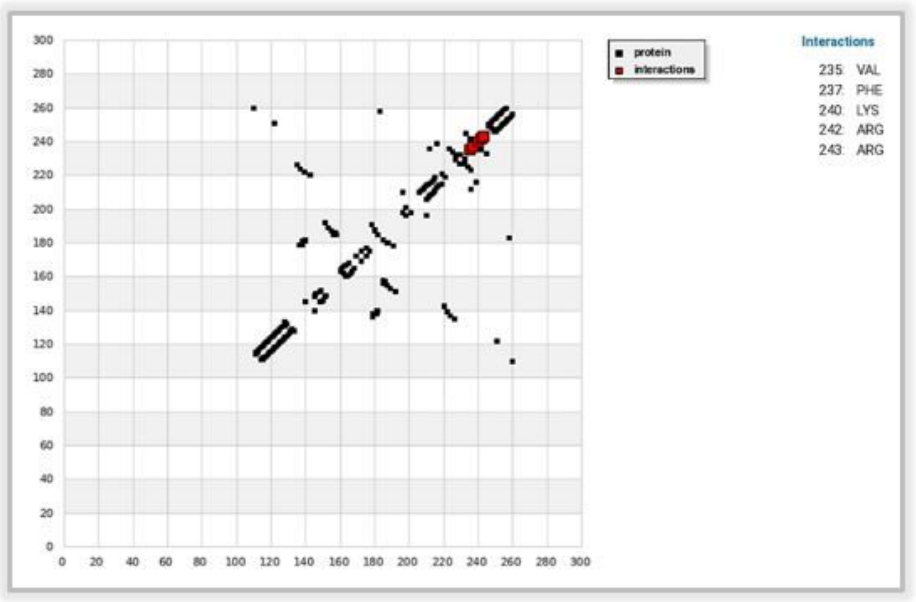

Figure 31

HB plot of interaction between ligands (A) HCPA and (B) HCMPPA and receptor of Staphylococcus aureus (PDB code: 6gyw) 


\section{(A)}

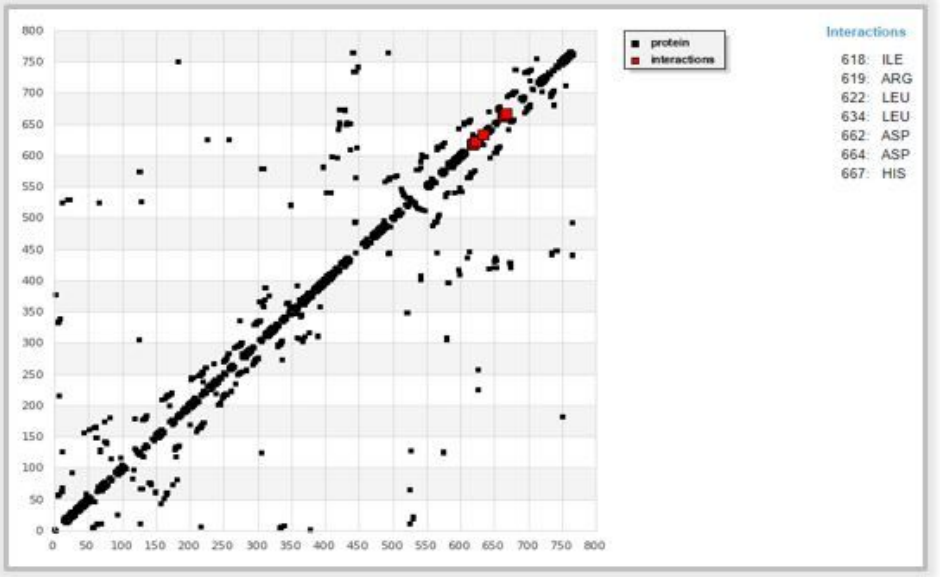

(B)

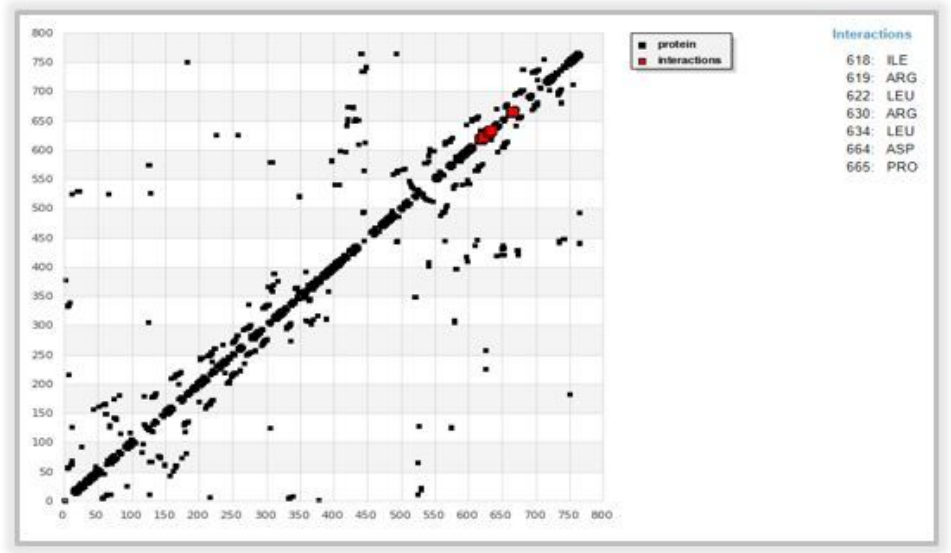

\section{Figure 32}

HB plot of interaction between ligands (A) HCPA and (B) HCMPPA and receptor of Candida albicans(PDB code: 3ppc) 


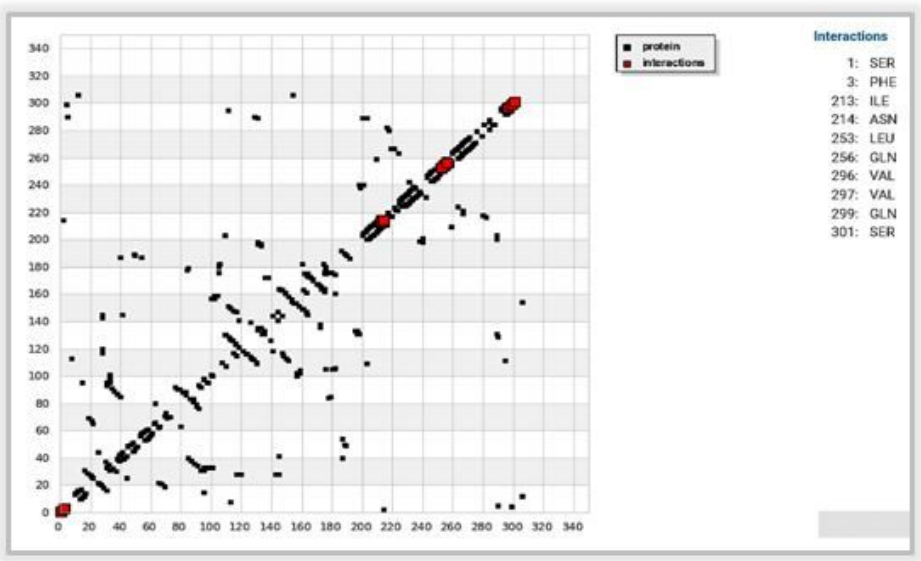

(B)

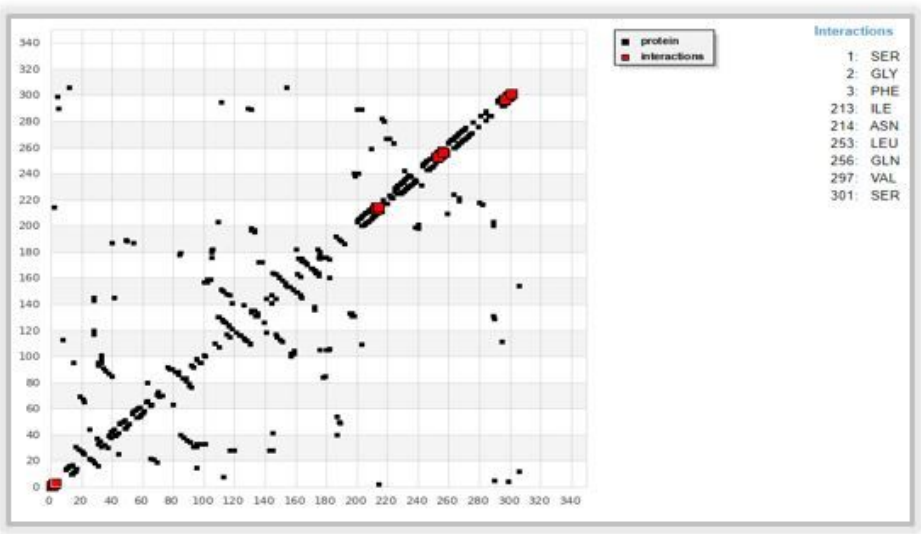

\section{Figure 33}

HB plot of interaction between ligand (A) HCPA and (B) HCMPPA and receptor of Covid 19 (PDB code: 7jpy)

\section{Supplementary Files}

This is a list of supplementary files associated with this preprint. Click to download.

- scheme1.jpg

- scheme2.jpg

- scheme3.jpg

- scheme4.jpg

- supplementary.docx 